\title{
Offshore Structural Reliability Assessment by Probabilistic Procedures-A Review
}

\author{
Sayyid Zainal Abidin Syed Ahmad ${ }^{1}$ (D), Mohd Khairi Abu Husain ${ }^{2, *}$, Noor Irza Mohd Zaki ${ }^{2}$, \\ Nurul Azizah Mukhlas ${ }^{2}$, Ezanizam Mat Soom ${ }^{3}$, Nurul Uyun Azman ${ }^{4}$ and Gholamhossein Najafian ${ }^{5}$
}

check for updates

Citation: Syed Ahmad, S.Z.A.; Abu Husain, M.K.; Mohd Zaki, N.I.; Mukhlas, N.A.; Mat Soom, E.; Azman, N.U.; Najafian, G. Offshore Structural Reliability Assessment by Probabilistic Procedures-A Review. J. Mar. Sci. Eng. 2021, 9, 998. https://doi.org/10.3390/jmse9090998

Academic Editor: Alessandro Antonini

Received: 9 August 2021

Accepted: 8 September 2021

Published: 13 September 2021

Publisher's Note: MDPI stays neutral with regard to jurisdictional claims in published maps and institutional affiliations.

Copyright: (c) 2021 by the authors. Licensee MDPI, Basel, Switzerland. This article is an open access article distributed under the terms and conditions of the Creative Commons Attribution (CC BY) license (https:/ / creativecommons.org/licenses/by/ $4.0 /)$.
1 Department of Maritime Technology, Faculty of Ocean Engineering Technology and Informatics, Universiti Malaysia Terengganu, Kuala Nerus 21030, Malaysia; s.zainal@umt.edu.my

2 Department of Engineering, Razak Faculty of Technology and Informatics, Universiti of Teknologi Malaysia, Kuala Lumpur 54100, Malaysia; noorirza.kl@utm.my (N.I.M.Z.); nazizah37@graduate.utm.my (N.A.M.)

3 Repsol Oil and Gas Malaysia Limited, Jalan Ampang, Kuala Lumpur 54450, Malaysia; nizamsoom76@gmail.com

4 Brunei Shell Petroleum, Jalan Utara, Panaga KB2933, Brunei; nuruluyuna@gmail.com

5 School of Engineering, The University of Liverpool, Liverpool L69 3GQ, UK; najafian@liv.ac.uk

* Correspondence: mohdkhairi.kl@utm.my

\begin{abstract}
Offshore installations must be built to resist fatigue as well as extreme forces caused by severe environmental conditions. The structural reliability analysis is the popular practise to assess a variety of natural waves determined by the long-term probability distribution of wave heights and corresponding periods on the site. In truth, however, these structures are subjected to arbitrary wave-induced forces in the open ocean. Hence, it is much more reasonable to account for the changed loading characteristics by determining the probabilistic characteristics of the random loads and outcomes responses. The key challenges are uncertainties and the non-linearity of Morison's drag element, which results in non-Gaussian loading and response distributions. This study would analyze advances achieved to date in a comprehensive probabilistic review of offshore fixed jackettype platforms.
\end{abstract}

Keywords: offshore structures; structural reliability analysis; probabilistic modelling; probability distribution; extreme responses

\section{Introduction}

Sea surface elevation is always random phenomena that continuously change in space and time [1]. An analytical mathematical model is not reasonable to describe the actual condition of sea surface elevation, but stochastic procedures can make an illustration of the sea surface elevation [2]. For practices related to sea state statistics, the sea surface is usually described by at least two parameters from either wind speed, wave height, wave period, peak period, or wavelength etc. $[3,4]$. In this study, Met-Ocean historical (or hind-cast) data of wave height $(H)$ and wave period $(T)$ is considered.

As stated by Vanem, et al. [5], through statistical wave analysis, it is possible to describe the sea surface elevation using the aforementioned parameters. Once the sea surface elevation is known, the wave-induced loads and its responses of offshore structures can be simulated regarding the schematic of ocean wave mechanics [6,7], as described in Section 3.3. In order to obtain the extreme structural responses induced by wave loads, various approaches have been proposed for defining the maximum values according to its return period $[8,9]$.

Therefore, the prediction of extreme response values by long-term analysis related to a specific return period is utilized as design waves $[10,11]$. Usually, the design wave based on API standards consider a return period of 25 years, 50 years or 100 years for extreme occurrences, which refers to structural responses (i.e., base shear, overturning moment etc.) that are used in the offshore structural assessment [12]. Specifically, the structural assessment 
can be implemented either by employing a deterministic or probabilistic approach. This approach, associated with the calculated design wave, is described in Section 2.1 below.

\section{Overview of the Offshore Structural Assessment}

A fixed offshore platform is exposed to different types of loads in the ocean environment. Usually, the loads acting on offshore structures can be classified into dead (permanent) loads, live (operating) loads, environmental loads, deformation loads, installation (construction) loads, and accidental loads [13-16]. In this study, the harsh environmental load conditions such as wind, wave, current including marine growth effects are considered as the influential loadings in the design of offshore structures $[17,18]$, in which the wind-induced wave load impact is the most dominant loads [19]. Thus, the estimated structural response is required to be used in the structural reliability assessment in order to check the structure integrity of platforms.

Structural integrity is a part of design engineering, which deals with the capability of a structure to sustain a designed structural capacity (weight, force, etc.) without breaking structural components $[20,21]$. Structural failure denotes the deterioration (loss) of structural integrity or the loss of the load-carrying ability of a structural component. Ensuring sustainable structure lifespan, predicting wave loads and structural responses on the fixed offshore platform are required for assessing the structural strength capability $[22,23]$. The structural strength (resistance) of the offshore platform is a significant part of reaching a reliable and vigorous design exceptionally capable of withstanding the extreme environmental loadings [21].

In order to achieve safe conditions, one of the plans to succeed in this task is by implementing a structural reliability analysis [24]. Structural reliability analysis (SRA) is implemented to guarantee the required design loads (structural responses) and its equivalent resistance load for the offshore platforms [25]. Moan [26] presented that offshore platforms are designed and assessed by reliability-based assessment to prevent any structure collapses based on the safety and structure integrity specifications.

\subsection{Structural Reliability Analysis for Fixed Offshore Platforms}

The idea of safety may be described as the non-existence of accidents, disasters, or failures. Safety and reliability are associated with the design stages of the structure's longevity (lifetime) [27-29]. As explained by San Tint [30], a profound level of safety is the probability that the offshore structures or other components will remain safe for the specified period. The safety assessment is carried out by performing probabilistic-based structural reliability analysis, which requires the coupled loads of design (stress) and resistance (strength) as main models [31]. Such probability models will be then assessed in limit state function to achieve the platform's probability of failure (POF) in specific comparative periods [32].

In practice, the design of the structure is determined related to the return period (e.g., 100-year event) [33]. In order to ensure the structure design meets the crucial prerequisite of acceptable SRA, the safety performance will be analyzed with regard to the POF associated with the reliability index [34,35]. Thus, the SRA can be described as the probability of the structure having proper appearance throughout its lifetime [36,37]. Figure 1 illustrates how the probabilistic approach is used in the structural assessment, which is the calculation of the extreme structural responses adopted to assess the structure failure (POF of offshore structures). The probabilistic approach was preferred in this study to account for all sorts of uncertainties in the stochastic load and resistance modelling, whereas the deterministic approach inaccurately assesses when dealing with random processes. 


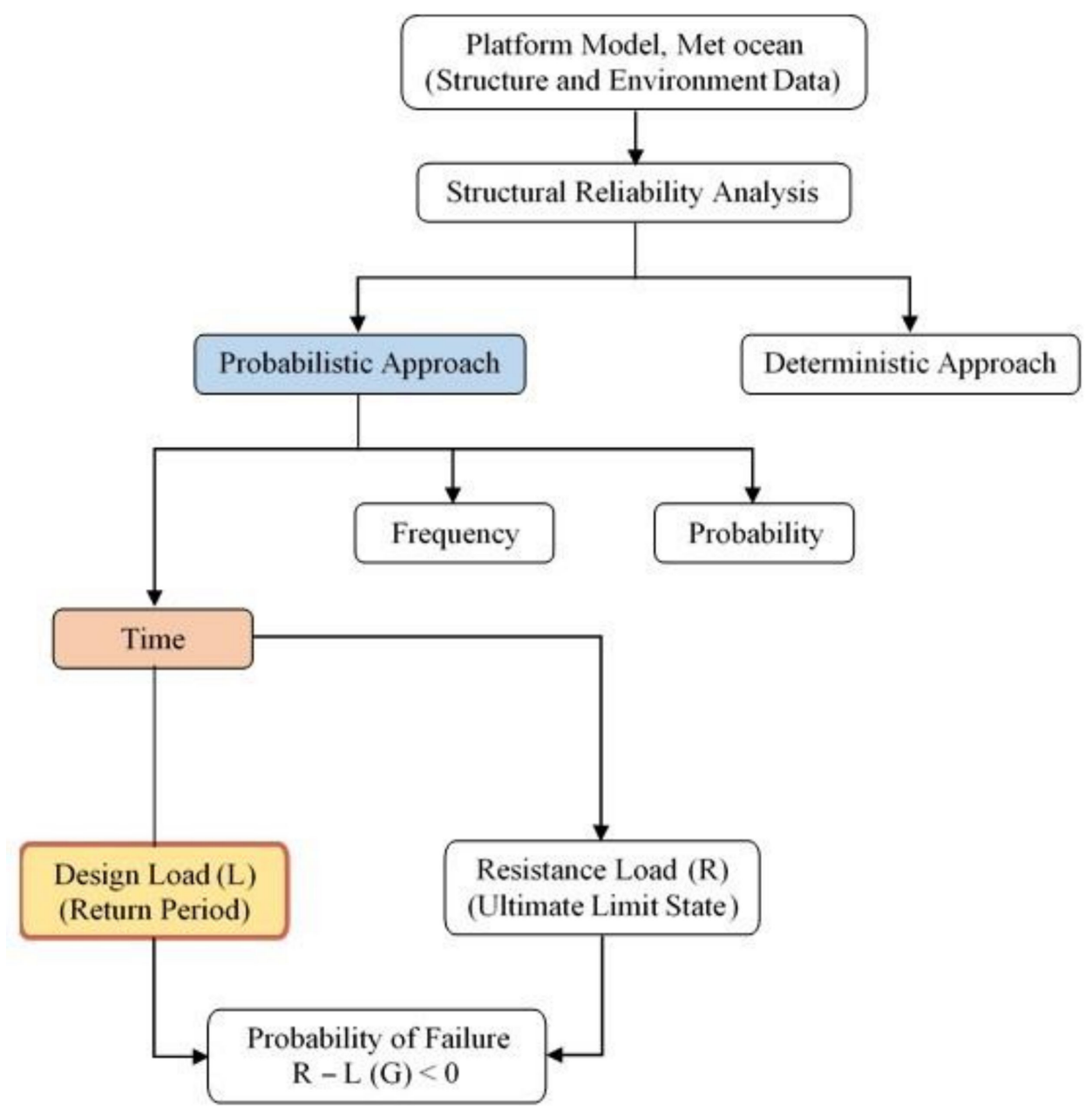

Figure 1. Determination of the probability of failure using the structural reliability analysis approach.

For performing the structural assessment, the computer numerical analysis is initiated by calculating the offshore hydrodynamics (wave motion, acceleration, loads), which are imposed on the platform model based on Met-Ocean data provided [38,39]. Based on the probabilistic approach [40], the measurement of safe structures between design and resistance loads could be determined. From this gathered data collection, the offshore structures that depend on the data records of stress (design) loads caused by environmental loads (i.e., wind-induced wave and currents) is calculated first [41]. Then, the strength (resistance) loads that occur due to the environmental load, gravity load, material, and geometric variability is defined below ultimate limit state [42,43].

To ensure the structural integrity can cope with the extreme waves, the design load (stress model) should not exceed the resistance (strength model) of the platform structures. As displayed in Figure 2, once the stress is greater than the strength, the possibility of the structure's collapses, or POF fails, results in higher chances of failure. A decrease in the POF can be assumed equal to the increase of safety [44]. The approximated POF depends on the value of reliability index, which is the space from the origin (mean model distribution) to the limit state function $[33,45]$. Thus, a fair safety margin must be designated with the POF that can regulate the overlap red area scale. Once the longest distance of reliability index is obtained [46], a red zone could be minimized, which decrease the POF directly. 


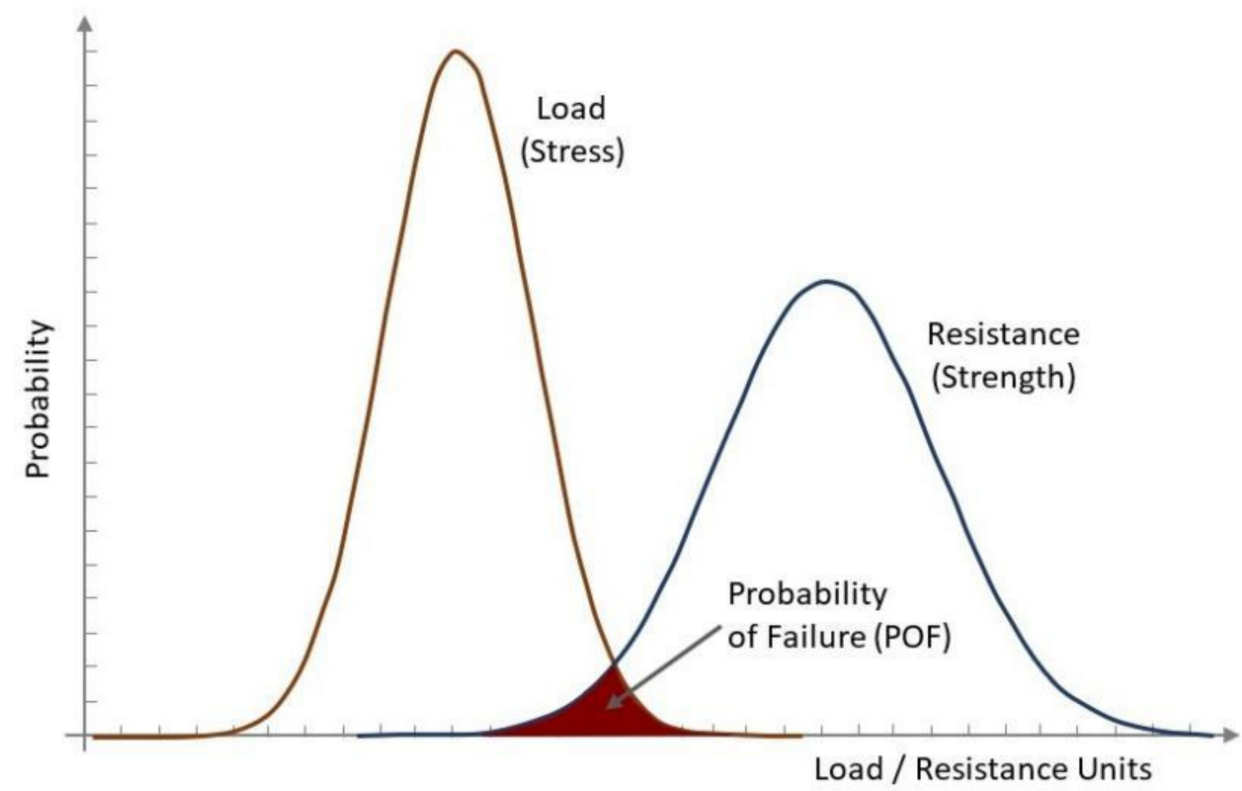

Figure 2. Probability of failure of load-resistance normal assumption.

In order to evaluate POF of the platform, a simple design procedure based on the failure threshold (return period) of the probability distribution of structural responses is considered [36]. The procedure is on the basis of the structural reliability method following the given Equation (1), in which the POF function is described accordingly [20]:

$$
\mathrm{POF}=P(R \leq L)=P[G(R, L) \leq 0]
$$

where $P O F$ is the probability of failure, $P$ is the probability distribution (model), $R$ is the system's "resistance" (or ultimate limit state/strength), $L$ is the system's "loads" (or assessed structural response distribution from environmental load effects), and $G$ is the function of failure, which could be represented as $G=R-L$.

In reliability assessment, the POF was developed in reliability engineering to analyze structural safety and execute reliability analysis $[47,48]$. This means that when the POF number declines, the offshore structure and other structures become more reliable. In this context, reliability may be described as a 1 in 100 or 1 failure in 100 probability [46]. Hence, a static pushover analysis or a nonlinear collapse analysis such as SACS and USFOS is extensively employed by various oil and gas organizations in order to obtain the RSR and POF values based on ultimate base shear over a design return time [37,49]. In this analysis, the probabilistic approach-based probability, frequency, and time domains are discussed in more detail. Regarding load analysis procedure, the wave load-induced responses are then simulated based on numerical wave modelling

\subsection{Determination on the Wave Force Procedure}

In order to calculate the extreme wave and its related current forces for static analysis in correct sequences, the typical requirement is provided by the American Petroleum Institute (API) standard according to the recommended practice (RP) of 2A (API RP 2A). Since the Met-Ocean data is associated with this standard [50], the API RP-2A procedure is utilized, as illustrated in Figure 3. Thus, this wave force procedure including the twodimensional wave theory, the current kinematics, the surface roughness led by marine growth is referred to in calculating the wave force in Morison's equation. All related topics will be discussed in Section 3. 


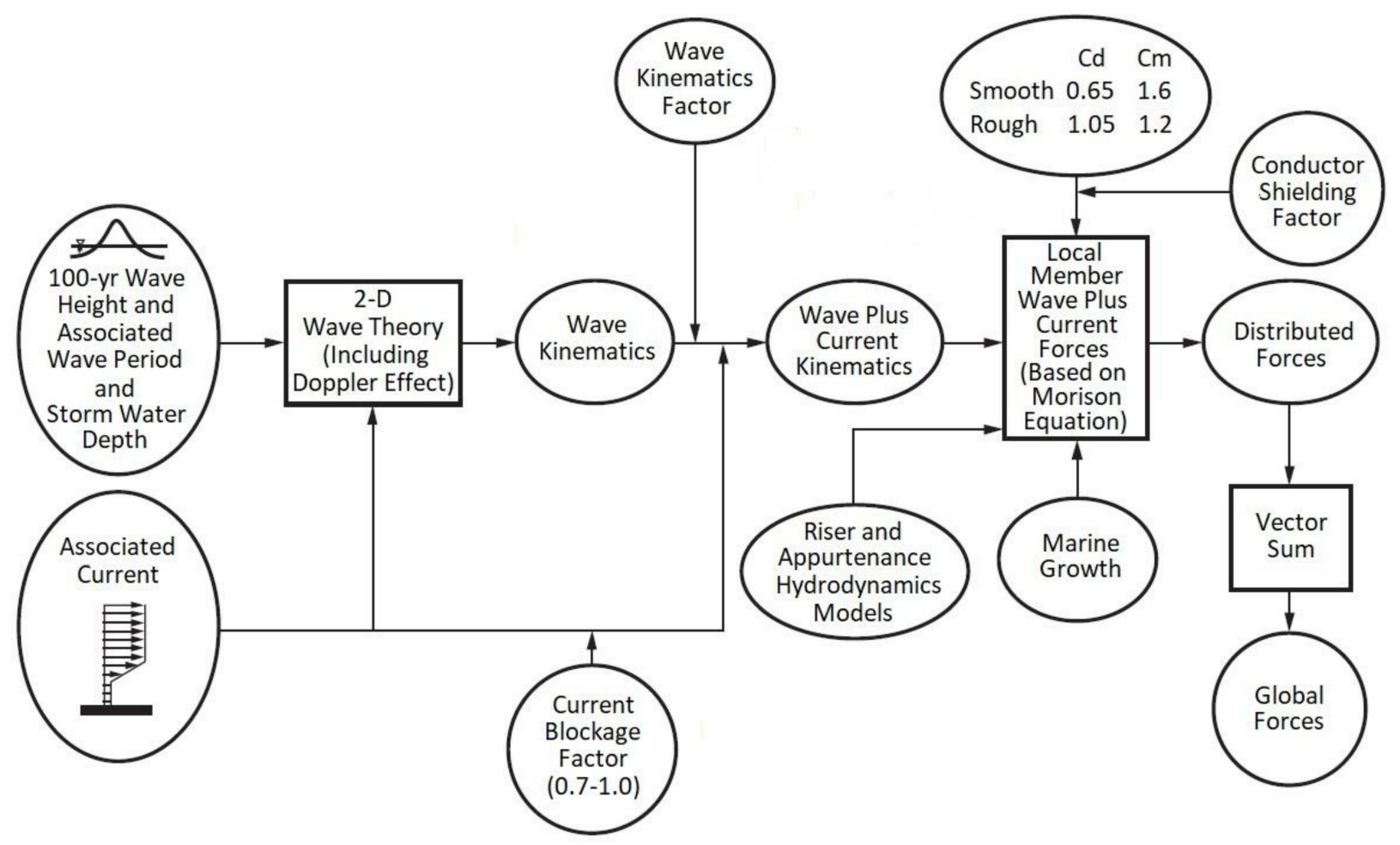

Figure 3. Wave force calculation procedures.

Based on this procedure, it is universal enough to be applicable in all structures for the estimation of extreme wave forces. Due to the impact of the random nature of waves, the calculation of extreme responses could be realized by stochastic processes using specific ocean-wave modelling and its statistical analysis [51]. Before proceeding into the random processes, each stage of calculations should be followed orderly related to the API RP-2A guidelines, as explained in Section 3.1.

\subsection{Analysing Hydrodynamic Wave Load-Induced Offshore Structural Responses}

As a practice, the sea surface elevations (surfaces waves) could be acquired by three methods: theoretical analysis, either field experiments or laboratory experiments and digital simulations [52-54]. In this study, the analysis focuses on the digital (numerical) simulations, which include hybrid time-frequency domain simulation as the basis. Under these domains as per Kareem and Kijewski [55], the Fourier transform method is used to transform the time domain into the frequency domain. Besides, the frequency domain (wave spectrum) could be transformed into the time domain (broadband form) using the inverse Fourier transform. This subsequent section explained briefly the numerical process of calculations related to statistical analysis.

\subsubsection{Numerical Simulation Analysis}

In the 1950s, Phillips' [56] effort was based on dimensional considerations and on the fact that due to the wave steepness, the high-frequency part of the spectrum is limited by wave breaking. Energy inputted by wind in these frequencies is lost by wave breaking. For that reason, Phillips elaborated the equilibrium range of spectrum in the portion of higher energy (in the band of frequencies from $1.5 \times f p$ to $3.0 \times f p$ ) and is independent of the wind speed and fetch. Phillips' equation is not used in practice, but the form became the basis for most subsequent wave spectra.

According to wave spectral formulations, a spectral analysis based on the fast Fourier transform will be carried out on all the times series for each wave record analyzed [7]. Conforming to Faltinsen [57], the wave elevation for a wide area where the sea is traveling along the $x$-axis, can be described as a summation of sinusoidal wave components. By the 
fundamental theory of waves [58-60], numerical analysis can generate the sea-wave surface elevation of irregular sea states until obtaining the wave loads and offshore structural responses. This is the key concept for describing the waves of the ocean regarding the ocean wave mechanics scheme $[6,61,62]$, as illustrated in Figure 4.

Numerical simulation

(Section 2.3)

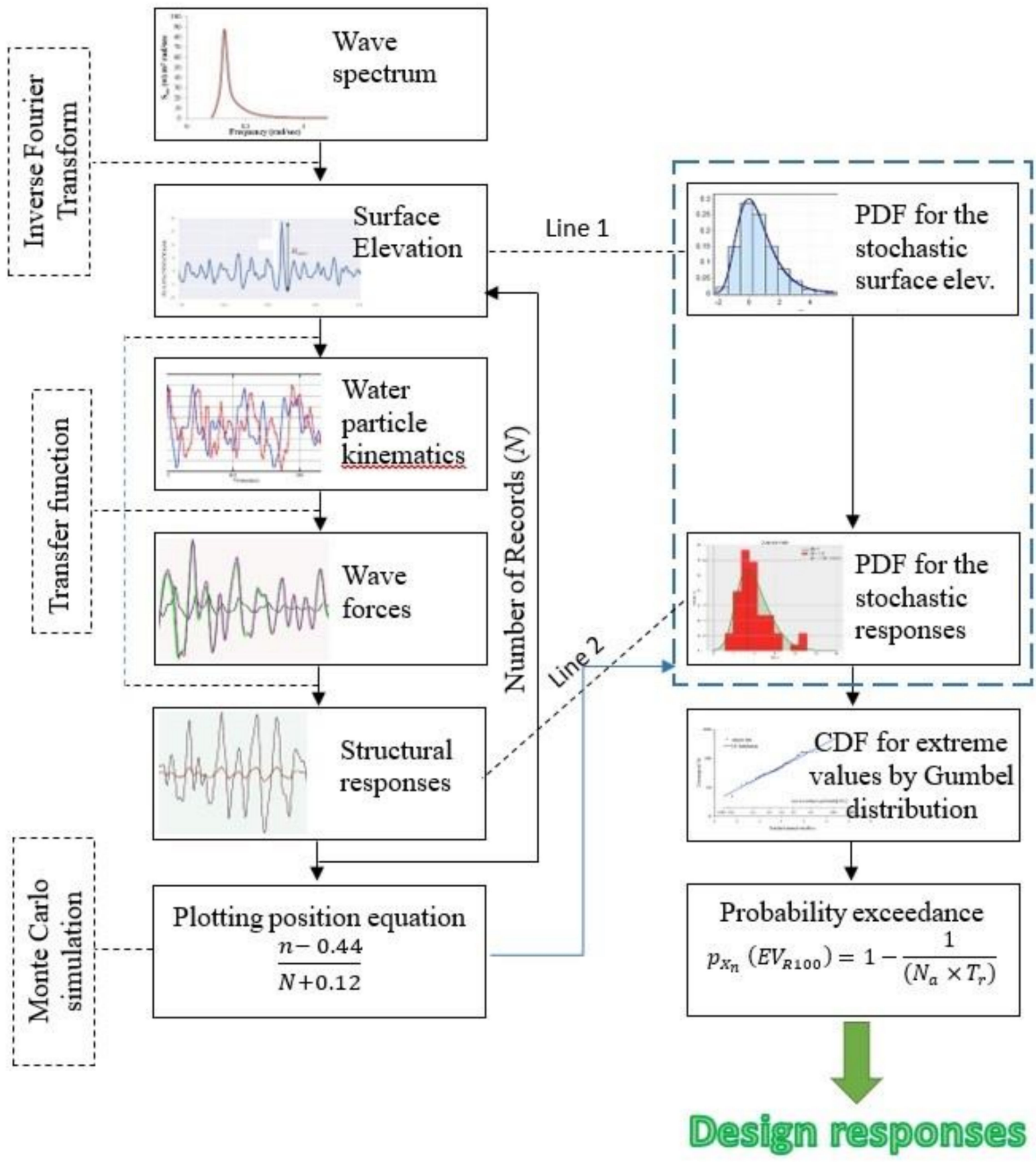

Figure 4. The numerical procedure and its statistical analysis of the structural response design based on the conventional methods in determining return periods. 


\subsubsection{Short-Term and Long-Term Analysis}

Analyzing the hydrodynamic flow field (wind, wave, and current) exerted on structures that the wave-induced load varies time in nature [63]. It is important to differentiate between short- and long-term definitions in the characterization of the sea climate. In the short-term definition, the state of the sea, which is called stationary, is described for a short period of time. In the long-term definition, the aim is to explain the transition in short term characterization over a long period of time, e.g., over the lifespan of the structure [64,65].

The short-term definition of the offshore platform architecture is used explicitly for the estimation of the wave loading. The long-term definition can be used to decide the most important definition of the short term sea condition in an investigation of the first excursion loss or in fatigue analysis to determine statistical variance in the different shorter sea states encountered by a platform [66]. Sea waves arising in a short time scale more closely follow the response time of fixed offshore structures and are described by deterministic definitions. The longer time frame correlates mostly to the structure's fatigue fracture and is defined as probabilistic.

In term of structure design, the short-term analysis is utilized as a first step to evaluate the probability of failure for a particular sea state in a specified timeline. Meanwhile, the long-term analyses take more realistic account of the total sea state condition (i.e., met-ocean data based on scatter diagram). The probabilistic approach could be used to calculate the design responses based on several domains.

\section{Probabilistic Approaches for Fixed Offshore Structural Response Analyses}

A systematic technique to calculate all statistical data associated to uncertainties is a probabilistic analysis method [67-70]. Because of its capability on uncertainty, probabilistic analysis is suitable for simulating wave characteristics related to randomness mechanisms such as geometry, material properties, and measurement (i.e., wave load-induced responses) [71-73]. As reported by Karadeniz [74],Reid and Naess [75], Moon, et al. [76], uncertainty is a significant aspect that influences the accuracy of simulations in order to estimate the numerous simulated data of extreme structural responses.

Therefore, a probabilistic approach is the most encouraging way to predict sporadic wave-inducing forces in ocean environments [77]. The probabilistic method is more reliable in simulations [78], as it can quantify arbitrary wave load-induced responses in the ocean environment. Several different techniques have been presented for response assessments. In general, probabilistic structural analysis can be established in three modes; probability, frequency, or time domains [31,79-81]. Sections 3.1-3.3 give a detailed background of domains under probabilistic structural response analysis.

\subsection{Probability Domain Methods}

The basic concept of the probability domain used to calculate the responses was based on the assumption of wave forces from the theoretical Pierson-Holmes distribution [82]. In line with $[83,84]$, the hypothesis began with the mathematical model like wave spectrum, linear wave theory, water particle, wave load, and responses had been expressed into a simplified term of the variable used in the probability distribution function (PDF). By the probability and stochastic process, the hydrodynamic response was simulated employing the Gaussian technique based on the revised PDF [85]. Numerous simulated data are then tabulated into the probability density histogram. In order to determine extreme response values, the simple statistical techniques of second and fourth moments were analyzed [86].

In the probability domain, Burrows $[87,88]$ revealed that the Second-Fourth Statistical Moment (SFSM) approach alongside the Principal Component Technique (PCT) had used a linear wave theory, but the Simple Sampling Technique (SST) used the non-linear wave theory. All these approaches were tested on the structures by quasi-static responses. In terms of statistical analysis, only the SFSM method had performed both short-term and long-term analysis. However, the fourth statistical moment approach is extremely computationally challenging in assessing the structural responses. Therefore, Najafian, et al. [89] 
implemented the development of the random sampling method, allowing the scattered wave loadings to be idealized from a wide range of point loads. The technique is, however, effective only when used in high seas. At low seas, the unrelated water particle kinematic on the surfaces is assessed with a greater sample size accurately.

On the other side, Najafian, et al. [90] presented the SST technique in order to perform effectively in both high and low sea condition. A 'Gaussian Booster' enhances the sampling process by taking benefits from an auxiliary variable in the Gaussian response. Without taking into account the current impacts, load intermittency in the splash zone, and wave directionality in the process, this approach managed to significantly reduce computational effort for quasi-static responses consistently with a slight variability in the kurtosis study. For quasi-static reaction, this technique has proved accuracy and highly effective.

None of the methods considered the current effect in their analyses, Najafian [91] introduced the PCT method, which was tested in the presence and absence of current propagation including load intermittence. Researchers have suggested a simpler way to minimize complexity with the use of the PCT for various random variables. A set of uncorrelated variables known as principal components that are linear to the initial variables characterize much of the correlated (clustered) random variables. It will then produce an individual response that is counter to the associated time simulation and results in a smaller sampling variability. Yet, the development considered for quasi-static structural analysis is neither short-term nor long-term analysis. Currently, under this domain, as presented in Table 1, the PCT system was the latest method for quasi-static assessment.

Table 1. Probability domain method in evaluating extreme responses.

\begin{tabular}{|c|c|c|c|}
\hline $\begin{array}{l}\text { Author } \\
\text { (Year) }\end{array}$ & Method & Findings & Limitations \\
\hline $\begin{array}{l}\text { Burrows R. } \\
(1977 \& 1983)\end{array}$ & $\begin{array}{c}\text { Second and Fourth } \\
\text { Statistical Moment } \\
\text { (SFSM) }\end{array}$ & $\begin{array}{l}\text { - A numerical analysis has been } \\
\text { implemented by the second and } \\
\text { fourth moments } \\
\text { A “cubic" approximator is } \\
\text { implemented and a linear/cubic } \\
\text { "optimum" approximator allows a } \\
\text { degree of numerical precision to be } \\
\text { reasonable in analysis }\end{array}$ & $\begin{array}{l}\text { This concept of SFSM was } \\
\text { originally confined to the } \\
\text { application of statistical criteria } \\
\text { relevant to the estimation of such } \\
\text { high-order assumptions }\end{array}$ \\
\hline $\begin{array}{l}\text { Najafian G., } \\
\text { Burrows R., } \\
\text { Tickell R.G., } \\
\text { Metcalfe A.V. } \\
\quad(2002)\end{array}$ & $\begin{array}{l}\text { An efficient sampling } \\
\text { technique known as } \\
\text { Simple Sampling } \\
\text { Techniques (SST) }\end{array}$ & $\begin{array}{l}\text { - Along with the "Gaussian Booster", } \\
\text { moment estimation could be } \\
\text { reached with superior precision due } \\
\text { to its importance sampling in } \\
\text { expressing structural quasi-static } \\
\text { responses } \\
\text { This technique was effectively } \\
\text { capable of assessing a large number } \\
\text { of nodal loads with lessening } \\
\text { computational effort }\end{array}$ & $\begin{array}{l}\text { Demand an improved } \\
\text { performance in CPU duration by } \\
\text { at least } 1000 \text { times for analyzing } \\
\text { the response kurtosis (when } \\
\text { compared to the time simulation } \\
\text { with similar case of accuracy level) }\end{array}$ \\
\hline $\begin{array}{l}\text { Najafian G. } \\
\text { (2007) }\end{array}$ & $\begin{array}{l}\text { Principal Component } \\
\text { Techniques (PCT) }\end{array}$ & $\begin{array}{l}\text { - The efficiency of PCT is greater than } \\
\text { MCTS by nearly } 25 \text { times } \\
\text { Decrease variation of unrelated } \\
\text { variables contributing to an efficient } \\
\text { evaluation of responses }\end{array}$ & $\begin{array}{l}\text { - The application of PCT approach } \\
\text { is mostly significant for the } \\
\text { assessment of quasi-static } \\
\text { structural responses }\end{array}$ \\
\hline
\end{tabular}

\subsection{Frequency Domain Methods}

Stochastic processes in the frequency domain had been previously practiced in the offshore oil and gas industry [92,93]. On the other hand, the frequency domain becomes another option to minimize computational demands, although it is less precise than the time domain $[94,95]$. This domain has been widely assigned to the marine structures, 
mainly offshore manufacturers. Marine designers in the offshore industry applied one such Volterra series-based model.

This series-based model enabled an estimation of offshore structural responses correlated with cumulant spectra (e.g., unispectrum, bispectrum, and trispectrum) [96-98]. The application of the Volterra model requires that polynomials are used to approximate the nonlinear Morison's drag term for defining the transfer functions. The model has two shortcomings that drastically decrease its applicability amid rising polynomial degrees: exciting increment of complexity in obtaining higher-order spectra [99] and immediately expanding numerical problems in computing the higher-order statistics [100].

In 1997, Naess and Pisano [101] performed research on dynamic structural analysis by applying a stochastic method. In his study, the current propagation is inconsiderable, and the splash zone is neglected. The recommended approach presented a correct forecast of the response, although it was restricted to linear structures. Kareem, et al. [102] explained that the nonlinearities' behavior forms an essential issue in the probabilistic method by using Stokes' perturbation expansion solution. Nevertheless, the investigation found that the platform is not subjected to the higher responses.

Therefore, it can be stated that the Volterra series can quickly estimate the nonlinearities of an uncomplicated system. Zheng and Liaw [103] also worked on the nonlinearity issues of wave forces and structural responses by a frequency-domain cumulant spectral analysis method. Ersdal [104],Puskar, et al. [105] first discussed a major problem on wave loading evaluation applying the Ultimate Force for Framed Offshore Structures (USFOS). This approach increased its efficiency in calculating the structural failure using USFOS nonlinear analysis. On the other hand, Marzocca, et al. [106] found Volterra functional series-spectrum analysis to solve the higher order in complex adaptive (dynamic). This theoretical approach is a better guide to help, for example (1) how non-linearities relate to the dynamics of the non-linear system, (2) how the computational methods of prediction are derived, (3) how the non-linear system analysis techniques are oriented, and (4) details on bispectrum responsiveness and the reliance on amplitude of such nonlinearities.

Carassale and Kareem [107] improved the technique utilizing the 5th Volterra model to determine the higher order of the nonlinear system. Even so, the model was restricted at a specific condition that affected reliability assessment. Agarwal and Manuel [108] presented the theory for a nonlinear irregular model and use it as part of the widely used wind turbine simulation program, FAST (Facilitated Application Specification Technique software). A powerful algorithm is used for nonlinear wave elevation and kinematic estimation, allowing for simple performance of large numbers of time-domain simulations for long-term load prediction with statistical extrapolation. The analysis focuses on higher estimation on the use of second-order wave theory than the first-order extreme offshore response in structures.

For reliability evaluation, Norouzi and Nikolaidis [109] introduced an improvised Probabilistic Re-analysis method. This method is based on the idea that a small failure probability can be calculated as a product of larger conditional probabilities of intermediate events. Consequently, this method is more efficient because it is much faster to calculate several large probabilities than a single low probability. Subsequently, Ebrahimian, et al. [110] presented a more detailed review of influencing factors that have an effect of uncertainty in the assessment process. However, this PIWA technique-based frequency domain has lower accuracy in relation to a complex nonlinear system such as more severe environmental conditions [110].

On the other side, when the wave height is equal to the diameter of the cylindrical structure, nonlinear effects could be excited and influence the steadiness oscillations by exhibiting steady or transient response. Furthermore, first-order wave theory, which uses linear constraints, does not explain wave kinematics in the wave field and then leaves out loads in the wave zone. Solving these issues, Chen [111] introduced the frequency range to be defined by the higher order terms added by the procedure that can best be calculated. Better estimation for extreme offshore structural responses in relation to first order for second-order theory. 
The simulations based on linear wave theory are currently considerably less predictive than nonlinear analysis $[110,112,113]$. While non-linear wave analysis still predicts offshore structural responses as a result of the wave load, it is more practical compared to linear wave analysis, as seen in the measurements and laboratories [114]. At least the addition of the second nonlinear term is necessary to provide the stochastic characteristic of the actual sea state, thus producing a better outcome for predicting the precision of extreme value responses [112,115]. In this respect, the contribution of higher-order Stokes modes to the linear approximation makes it more complicated and difficult to solve the equation.

Kim [115] developed a NARX (Non-linear Autoregressive with Exogenous Input) method. With this approach, a different higher-order frequency component is precisely calculated in the time series of the structural scheme responses, even the presence of random excitation. Following Mérigaud and Ringwood [116], an NLFD framework has the potential to be implemented on quadratization and cubicization of the nonlinear wave loads that facilitate great computational conservations in the estimation. In probabilistic based on frequency domains, Table 2 listed all the approaches with its respective results.

Table 2. Frequency domain method in evaluating extreme responses.

\begin{tabular}{|c|c|c|c|}
\hline $\begin{array}{l}\text { Author } \\
\text { (Year) }\end{array}$ & Method & Findings & Limitations \\
\hline $\begin{array}{l}\text { Olagnon M., } \\
\text { Prevosto M., } \\
\text { Joubert P. } \\
\text { (1988) }\end{array}$ & $\begin{array}{l}\text { Non-linear spectral } \\
\text { calculation based on } \\
\text { Volterra kernels }\end{array}$ & $\begin{array}{l}\text { - Fixed structures had been assessed } \\
\text { unto fourth-order moments of } \\
\text { dynamic responses } \\
\text { Volterra kernels are qualified to } \\
\text { forecast structural response efficiently } \\
\text { included nonlinearities features }\end{array}$ & $\begin{array}{l}\text { - Suitable for simple marine } \\
\text { structures }\end{array}$ \\
\hline $\begin{array}{l}\text { Li X.-M., } \\
\text { Quek S.-T., } \\
\text { Koh C.-G. } \\
\text { (1995) }\end{array}$ & Volterra series & $\begin{array}{l}\text { - The dynamic response moments up to } \\
\text { fourth order of fixed offshore } \\
\text { platforms can be estimated }\end{array}$ & $\begin{array}{l}\text { - } \quad \text { Applicable to simple structures } \\
\text { - The dynamic response moments } \\
\text { up to fourth order of fixed } \\
\text { offshore platforms can be } \\
\text { estimated }\end{array}$ \\
\hline $\begin{array}{l}\text { Tognarelli M.A., } \\
\text { Zhao J., } \\
\text { Rao K.B., } \\
\text { Kareem A. } \\
\text { (1997) }\end{array}$ & $\begin{array}{l}\text { Volterra functional } \\
\text { series }\end{array}$ & $\begin{array}{l}\text { Good prediction on higher order } \\
\text { statistical and power spectral density }\end{array}$ & $\begin{array}{l}\text { - Only applicable for simple } \\
\text { structures }\end{array}$ \\
\hline $\begin{array}{l}\text { Naess and Pisano } \\
\text { (1997) }\end{array}$ & $\begin{array}{l}\text { Exact computation of } \\
\text { probability density } \\
\text { functions }\end{array}$ & $\begin{array}{l}\text { - Have the capability to carry out a } \\
\text { dynamic interpretation of linear } \\
\text { structures }\end{array}$ & $\begin{array}{l}\text { - Limited to the linear marine } \\
\text { structure where the } \\
\text { wave-current is inconsiderable } \\
\text { without the splash zone } \\
\text { influence }\end{array}$ \\
\hline $\begin{array}{c}\text { Kareem A., } \\
\text { Hsieh C.C., } \\
\text { Tognarelli M.A. } \\
\text { (1998) }\end{array}$ & $\begin{array}{l}\text { Stokes' perturbation } \\
\text { expansion solution }\end{array}$ & $\begin{array}{l}\text { - } \\
\text { subjlinearities excitation were a vital } \\
\text { the design discipline. By ignoring this } \\
\text { matter, it may appear that random } \\
\text { wave loads are not preserved in } \\
\text { genuine statistical estimation }\end{array}$ & $\begin{array}{l}\text { - Higher responses are not } \\
\text { considered in this space }\end{array}$ \\
\hline $\begin{array}{l}\text { Zheng X.Y., } \\
\text { Liaw C.Y. } \\
\text { (2004) }\end{array}$ & $\begin{array}{l}\text { Cumulant spectral } \\
\text { analysis }\end{array}$ & $\begin{array}{l}\text { Fast Fourier transform (FFT) is } \\
\text { adopted to measure the tri-spectrum } \\
\text { of the load from its fourth order } \\
\text { cumulant function } \\
\text { The calculated load and response } \\
\text { kurtosis are observed to be more } \\
\text { efficient compared to time-domain } \\
\text { simulations }\end{array}$ & $\begin{array}{l}\text { Investigation to a realistic } \\
\text { marine structure with numerous } \\
\text { nodal loads is not investigated } \\
\text { in terms of efficiency }\end{array}$ \\
\hline
\end{tabular}


Table 2. Cont.

\begin{tabular}{|c|c|c|c|}
\hline $\begin{array}{l}\text { Author } \\
\text { (Year) }\end{array}$ & Method & Findings & Limitations \\
\hline $\begin{array}{l}\text { Ersdal G. } \\
(2005)\end{array}$ & $\begin{array}{l}\text { Stokes' analysis }+ \\
\text { USFOS }\end{array}$ & $\begin{array}{l}\text { Minimize the risk with the } \\
\text { probabilistic analysis model instead of } \\
\text { the failure probability criterion }\end{array}$ & $\begin{array}{l}\text { This analysis did not include } \\
\text { possible risks such as corrosion } \\
\text { and pile-related failures }\end{array}$ \\
\hline $\begin{array}{l}\text { Marzocca P. } \\
\text { Nicholsb J.M., } \\
\text { Milanesea A., } \\
\text { Seaverb M., } \\
\text { Trickeyb S.T., } \\
\quad(2008)\end{array}$ & $\begin{array}{l}\text { Volterra functional } \\
\text { series-spectrum } \\
\text { analysis }\end{array}$ & $\begin{array}{l}\text { Analytical solutions for a mechanical } \\
\text { system with quadratic damping, and } \\
\text { stiffness coefficients and subject to } \\
\text { white Gaussian noise excitation are } \\
\text { supported by the simulations based } \\
\text { on stochastic numerical integration } \\
\text { approach resulting bispectrum } \\
\text { calculations based on virtual signals. }\end{array}$ & $\begin{array}{l}\text { - As a practice, the nonlinear } \\
\text { processes should analyze the } \\
\text { higher-order relationships of the } \\
\text { data in order to completely } \\
\text { capture and identify the } \\
\text { statistical characteristic of } \\
\text { the response. }\end{array}$ \\
\hline $\begin{array}{l}\text { Carassale and } \\
\text { Kareem } \\
(2009)\end{array}$ & $\begin{array}{l}\text { Improved version of } \\
\text { Volterra } \\
\text { frequency-response } \\
\text { functions }\end{array}$ & - Solves higher order nonlinear systems & $\begin{array}{l}\text { - Unable to establish reliability } \\
\text { under current approach }\end{array}$ \\
\hline $\begin{array}{l}\text { Agarwal and } \\
\text { Manuel } \\
(2011)\end{array}$ & $\begin{array}{l}\text { Second-order wave } \\
\text { analysis + FAST } \\
\text { software }\end{array}$ & $\begin{array}{l}\text { Investigating the impact of wave } \\
\text { models in short-term distributions } \\
\text { and long-term loads of importance in } \\
\text { the designing of turbines }\end{array}$ & $\begin{array}{l}\text { - No further study on the impact } \\
\text { of environmental condition (e.g., } \\
\text { current) and short-term and } \\
\text { long-term analysis }\end{array}$ \\
\hline $\begin{array}{l}\text { Norouzi M., } \\
\text { Nikolaidis E. } \\
\quad(2012)\end{array}$ & $\begin{array}{l}\text { Extended probabilistic } \\
\text { re-analysis method }\end{array}$ & $\begin{array}{l}\text { - Calculating random dynamic } \\
\text { structural responses and predicting } \\
\text { the POF for the dynamic modes }\end{array}$ & $\begin{array}{l}\text { Considering numerous random } \\
\text { variables that makes it very } \\
\text { difficult to explore the space of } \\
\text { the random variables due to its } \\
\text { large dimension }\end{array}$ \\
\hline $\begin{array}{l}\text { Ebrahimian } \\
\quad(2014)\end{array}$ & $\begin{array}{l}\text { Probability } \\
\text { incremental wave } \\
\text { analysis (PIWA) }\end{array}$ & $\begin{array}{l}\text { PIWA technique by the application of } \\
\text { a Collapse Wave Height (CWH)-based } \\
\text { approach, which is suggested to } \\
\text { measure the mean annual frequency } \\
\text { (MAF) above the Collapse Prevention } \\
\text { (CP) limit condition. }\end{array}$ & $\begin{array}{l}\text { Decreased precision when faced } \\
\text { with a dynamic non-linear } \\
\text { system, such as more severe } \\
\text { ocean conditions. }\end{array}$ \\
\hline $\begin{array}{l}\text { Chen } \\
(2014)\end{array}$ & $\begin{array}{l}\text { Second-order wave } \\
\text { analysis }\end{array}$ & $\begin{array}{l}\text { The frequency spectrum to measure } \\
\text { the structure can be better described } \\
\text { with higher order terminology added } \\
\text { in wave analysis }\end{array}$ & $\begin{array}{l}\text { - Not considered aerodynamic } \\
\text { effect simulation would be a } \\
\text { more desirable approach to } \\
\text { examine the issue of } \\
\text { dynamic response }\end{array}$ \\
\hline $\begin{array}{l}\text { Natarajan } \\
(2014)\end{array}$ & $\begin{array}{l}\text { Second-order wave } \\
\text { analysis + HAWC2 } \\
\text { Software }\end{array}$ & $\begin{array}{l}\text { Better estimation for extreme offshore } \\
\text { structural responses in relation to first } \\
\text { order for second-order theory }\end{array}$ & $\begin{array}{l}\text { - Frequency cut-offs dependent } \\
\text { on the minimal curtosis of the } \\
\text { non-Gaussian wave phase }\end{array}$ \\
\hline $\begin{array}{l}\text { Kim O. } \\
(2015)\end{array}$ & $\begin{array}{l}\text { NARX-based } \\
\text { quadratic Volterra } \\
\text { series }\end{array}$ & $\begin{array}{l}\text { - An artificial neural network } \\
\text { established nonlinear recognition } \\
\text { system, was merged with the } \\
\text { harmonic technique to calculate the } \\
\text { time series of the structural responses } \\
\text { of a nonlinear scheme }\end{array}$ & $\begin{array}{l}\text { - The nonlinear behavior } \\
\text { influences the error in the } \\
\text { accurate prediction caused by } \\
\text { the massive marine structure } \\
\text { deformation }\end{array}$ \\
\hline $\begin{array}{l}\text { Merigaud A., } \\
\text { Ringwood } \\
\text { J.V. } \\
(2016)\end{array}$ & $\begin{array}{l}\text { Nonlinear } \\
\text { frequency-domain } \\
\text { (NLFD) }\end{array}$ & $\begin{array}{l}\text { NLFD shows promising potential } \\
\text { involving extensive simulation of } \\
\text { wave-energy converter (WEC) } \\
\text { applications with strong } \\
\text { nonlinearities assessment, while } \\
\text { preserving the WEC model accuracy }\end{array}$ & $\begin{array}{l}\text { Inappropriate for solving the } \\
\text { discontinuous derivatives of } \\
\text { dynamical equations }\end{array}$ \\
\hline
\end{tabular}

Kühn [117] proposed a simplified method for fatigue evaluation. Based on the frequency domain as a basis, the calculations of aerodynamic wave load on the structure could be reached via superimposing time-domain simulations. Later, Van Der Tempel [118] 
employed frequency domain analysis to achieve structure design, where a judgment of time-domain outcomes proved to be consistent and accurate. Recently, Seidel [119] proclaimed a profoundly uncomplicated procedure to determine if structural responses induced wave loads on the structures.

\subsection{Time Domain Methods}

In general, frequency-domain methods are efficient, but not as accurate as timedomain simulations. Time-domain simulation is applied to facilitate nonlinear analysis with linked simulations of wind and wave [120]. The time-domain analysis operated as the most accurate and regularly managed for verification purposes. Higher accuracy in results is an essential part of the analysis, particularly for proving ] time-domain methods. However, time-domain analysis demands an excessive volume of computer run-time due to the nonlinearity consideration in calculations [121].

Previous researchers have revealed multiple time-domain methods, including the Monte Carlo Time Simulation (MCTS), NewWave theory (NWT), Constrained New Wave (CNW), Finite-Memory Nonlinear System (FMNS), Efficient Time simulation (ETS), and Efficient Threshold Upcrossing (ETU). Beginning with Orkin, et al. [122], this study describes the way that the MCTS procedure is used to help design an offshore terminal system in a very hostile environment. By structural analysis, nonlinear excitation under random responses needs the MCTS method with hundreds of thousands of simulated records [123]. In their study, the MCTS method accurately evaluates the responses of fixed platforms, which are used as benchmarks in deriving the short-term and long-term probability distribution of extreme responses.

Further research work is also required in the model development to improve the accuracy towards MCTS methods. In addition, many researchers tried to improve the level of efficiency of simulation-based methods. Tromans, et al. [124] were the first to present the NWT in a time-domain method. This scheme involves the derivation of the probability distribution of extreme responses. In this method, the separation of the NewWave crest elevation is computed, employing the auto-correlation function of a sea state. The rationale of autocorrelation is to interpret the Fourier transform of the frequency spectrum. On the other side, Taylor et al., (1997) introduced a technique by the addition of two non-random functions. This technique considers short constrained simulations in order to determine the largest response correlated with a specified crest.

In order to overcome this previous problem, the NWT was expanded to a second-order approach that analyses the non-linearity of random waves [125-127]. After that, an idea of CNW theory is developed by [128], which is produced by mathematically constraining a NewWave within random time series, allowing the irregularity of ocean waves to be considered. These wave theories have been extended in this thesis to include 2nd-order and directionality effects, and their formulations have been written into a new Fortran code for calculation of the water surface and water particle kinematics. The effects of irregularity, directionality, and nonlinearity of ocean waves on dynamically sensitive structures are then shown for examples for the mobile jack-up drilling platform.

Cassidy, et al. [129] developed a probabilistic model to calculate the statistical extreme response and failure of jack-up structures considering different sources of uncertainties in loading and structural and foundation modelling and demonstrated that the uncertainties in the values of some of the essential variables could significantly affect the extreme response statistics. CNW theory and an advanced model to consider spud can-soil interactions were used to perform a dynamic evaluation on sample jack-up offshore platforms. In further studies, an association MCTS method is linked with a resulted linear extrapolation procedure in a central processing unit (CPU) for time-saving.

Naess, et al. [130] introduced a simple and robust technique in order to compute the extreme offshore structural responses without any simplifying exceeding those indirectly expressed in any computers. Linear extrapolation technique applied MCTS approach and optimized it with linear extrapolation for more accurate prediction. This method is 
an extension of MCTS method utilizing linear extrapolation procedure followed in the time-saving CPU to determine extreme response statistics. It is robust and straightforward, which counts all nonlinear influences without any oversimplification exceeding these embedded in any computer models. The outcome was authenticated by utilizing the MCTS method by varying sea states for the 100 years. This technique was used as a structural analysis for jacket platforms, which is more accurate, while at the same time, diminished sampling variability relies upon the same number of simulated records as that of MCTS method.

Najafian [131,132] later applied the same approach to predict the extreme response values and introduced a finite-memory nonlinear system designed for a further efficient procedure. Najafian and Zaki [133] announced a new procedure called the FMNS method. Note that the proposed technique offered an efficient procedure in simulating the structure response and provided good accuracy on the prediction of extreme response values. This procedure comprises three major systems, which are system A (linear system), system B (zero-memory nonlinear system), and system C (linear system). The result of FMNS method demonstrated to be more efficient than the MCTS procedure by a scale of 35 times. However, the outcomes indicate the level of accuracy reduced at low wave height.

In order to improve the FMNS technique, Najafian and Zaki [133] and Mohd Zaki, et al. [134] proposed a new approach using a modified finite-memory nonlinear system (MFMNS). This was done by separating the structure into two zones and applying the FMNS technique separately based on the zone, and the responses obtained were added to be employed to generate the probability distribution for the purpose of predicting an extreme response value. This was required to ensure a good correlation of water particle kinematics at the corresponding zone due to the shorter wavelength. However, the accuracy reduced once the current was considered in the analysis. The relationship of responses based on the corresponding technique was demonstrated.

On the other hand, Abu Husain and Najafian [135] pioneered an ETS method to resolve the sampling variability obstacle in the MCTS method. The ETS method uses the superiority of the excellent relationship between two variables of extreme surface elevation and extreme structural responses. To end this, the ETS method was compared with the benchmark of the MCTS method by deriving them into the probability distribution of extreme responses. The ETS method was validated with the results of the MCTS method. Thus, the ETS method analyzed two versions of the wave conditions. As a result, this ETS method was revealed to be a more efficient approach for determining high sea state intensity than the low sea state. The ETS method offered a more precise result at high sea state compared to the low sea state.

The unique approach merges the speed of the ETS method with excellent accuracy based on threshold up crossings identified as Efficient Threshold Upcrossing (ETU) by [136]. This approach is related to the ETS system, but it removes more numerous sample data records. The result of the ETU method was insignificantly more constant than the ETS method. However, the ETU method is restricted to the quasi-static structural responses without consideration of wave-current and intermittency load around the splash zone.

In a previous study, Mallahzadeh, et al. [137] conceived an extremely efficient simulation technique known as the Relationship Time Simulation (RTS) procedure. At the beginning of its appearance, this RTS technique is established by taking advantage of their relationship from ETS methods [138]. Based on this relationship, an empirical model was derived from the given sample data to be used in the probability distribution to predict the extreme structural responses. Mallahzadeh's ideas were proposed as a new concept from efficient time simulation (ETS) procedure in order to extemporize current ETS methods [139].

This concept was known as an Efficient Time Simulation-Relationship (ETS-RTS) method employed to improve accuracy and efficiency from MCTS method. Due to the study limitations, Mallahzadeh's study was focused only on the single-legged structure problem, and the method was only validated for high sea state intensity. Thus, the pro- 
posed approach used in this study was from this conceptual study, which expended more details on cases of wave conditions including criteria consideration. Table 3 outlined the entire procedure with its associated performance in the probabilistic analysis based on time domains.

Table 3. Time domain method in evaluating extreme responses.

\begin{tabular}{|c|c|c|c|}
\hline $\begin{array}{l}\text { Author } \\
\text { (Year) }\end{array}$ & Method & Findings & Limitations \\
\hline $\begin{array}{l}\text { Orkin, G., } \\
\text { Folck, R., } \\
\text { Startzman, R. } \\
\quad(1978)\end{array}$ & $\begin{array}{l}\text { The Conventional } \\
\text { Time Simulation } \\
\text { (CTS) or so-called } \\
\text { Monte Carlo Time } \\
\text { Simulation (MCTS) }\end{array}$ & $\begin{array}{l}\text { This type of simulation is a } \\
\text { mainstream approach to } \\
\text { reproduce the random process } \\
\text { such as the sea-state or } \\
\text { climate season }\end{array}$ & $\begin{array}{l}\text { - Need extensive simulation in } \\
\text { order to ensure estimation } \\
\text { measurement is satisfying to the } \\
\text { real values }\end{array}$ \\
\hline $\begin{array}{c}\text { Tromans, P. S., } \\
\text { Anaturk, A. R., } \\
\text { Hagemeijer, P. } \\
\text { (1991) }\end{array}$ & New Wave Theory & $\begin{array}{l}\text { The extreme response values for a } \\
\text { few representative wave crest } \\
\text { elevations can be determined } \\
\text { Provides a rational model for the } \\
\text { extreme waves }\end{array}$ & $\begin{array}{l}\text { - In the case of dynamic structures, } \\
\text { the response is dependent on both } \\
\text { current and previous values } \\
\text { of loading } \\
\text { - The extreme responses could be } \\
\text { defined from several illustrative } \\
\text { examples of wave crest heights } \\
\text { Valid only for a Gaussian } \\
\text { sea (linear) }\end{array}$ \\
\hline $\begin{array}{l}\text { Taylor P. H., } \\
\text { Jonathan P., } \\
\text { Harland L. A. } \\
\quad(1997)\end{array}$ & $\begin{array}{l}\text { Constrained time } \\
\text { domain simulation }\end{array}$ & $\begin{array}{l}\text { A notable advancement in } \\
\text { determining the statistics of } \\
\text { extreme responses for dynamic } \\
\text { structural responses is introduced }\end{array}$ & $\begin{array}{l}\text { - Applying the Morison's equation } \\
\text { with the existence of a huge waves }\end{array}$ \\
\hline $\begin{array}{l}\text { Cassidy M.J., Taylor, } \\
\text { P.H., Taylor, RE., } \\
\text { Houlsby, G. T. } \\
\text { (2001 \& 2002) }\end{array}$ & $\begin{array}{l}\text { Constrained New } \\
\text { Wave }(\mathrm{CNW})\end{array}$ & $\begin{array}{l}\text { Developed model in assessing the } \\
\text { hydrodynamic of jack-ups by } \\
\text { considering nonlinearities } \\
\text { in calculations }\end{array}$ & $\begin{array}{l}\text { - Focusing on the jack-ups } \\
\text { applications, which is only } \\
\text { subjected to the } \\
\text { short-term analysis }\end{array}$ \\
\hline $\begin{array}{l}\text { Naess, A., } \\
\text { Gaidai, O., } \\
\text { Haver, S. } \\
(2007)\end{array}$ & $\begin{array}{l}\text { Linear extrapolation } \\
\text { technique }\end{array}$ & $\begin{array}{l}\text { A combination of two methods } \\
\text { consisted of MCTS and CPU } \\
\text { timesaving techniques. Both } \\
\text { methods utilized a linear } \\
\text { extrapolation technique for } \\
\text { predicting extreme } \\
\text { response values }\end{array}$ & $\begin{array}{l}\text { Enormously depend on the same } \\
\text { number of simulated records in } \\
\text { keeping its accuracy level }\end{array}$ \\
\hline $\begin{array}{c}\text { Najafian G. } \\
(2007 a \text { \& 2007b) }\end{array}$ & $\begin{array}{l}\text { Finite-memory } \\
\text { nonlinear system } \\
\text { (FMNS) }\end{array}$ & $\begin{array}{l}\text { Developed FMNS model that is } \\
\text { able to simulate extreme } \\
\text { responses more effectively than } \\
\text { MCTS methods }\end{array}$ & $\begin{array}{l}\text { The developed model is accurate } \\
\text { as compared to the MC time } \\
\text { simulation technique }\end{array}$ \\
\hline $\begin{array}{l}\text { Mohd Zaki N.I., } \\
\text { Najafian G. } \\
(2008)\end{array}$ & $\begin{array}{c}\text { Finite-memory } \\
\text { nonlinear system } \\
\text { (FMNS) }\end{array}$ & $\begin{array}{l}\text { - Proposed best model of FMNS } \\
\text { that is more accurate than } \\
\text { previous FMNS model }\end{array}$ & $\begin{array}{l}\text { The accuracy reduced for lower } \\
\text { sea intensity }\end{array}$ \\
\hline $\begin{array}{c}\text { Abu Husain M.K., } \\
\text { Najafian G. } \\
(2010)\end{array}$ & $\begin{array}{l}\text { Efficient time } \\
\text { simulation (ETS) }\end{array}$ & $\begin{array}{l}\text { As observed, an ETS method is } \\
\text { more effectual and approximately } \\
\text { 10x times more effective than the } \\
\text { MCTS method } \\
\text { Excellent efficiency by reducing a } \\
\text { certain number of simulations } \\
\text { without affecting its level } \\
\text { of accuracy }\end{array}$ & $\begin{array}{l}\text { - Very poor and inaccurate } \\
\text { estimation of extreme responses at } \\
\text { low sea state. } \\
\text { - Only relevant for the high wave } \\
\text { Hs values }\end{array}$ \\
\hline
\end{tabular}


Table 3. Cont.

\begin{tabular}{|c|c|c|c|}
\hline $\begin{array}{l}\text { Author } \\
\text { (Year) }\end{array}$ & Method & Findings & Limitations \\
\hline $\begin{array}{l}\text { Mohd Zaki N.I., } \\
\text { Abu Husain M.K., } \\
\text { Mallahzadeh H., } \\
\text { Najafian G. } \\
\text { (2013) }\end{array}$ & $\begin{array}{l}\text { Modified } \\
\text { Finite-Memory } \\
\text { Nonlinear System } \\
\text { Modelling (FMNS) }\end{array}$ & $\begin{array}{l}\text { Prediction of an extreme response } \\
\text { derives into probability } \\
\text { distribution of extreme responses } \\
\text { with excellent performance in } \\
\text { terms of efficiency ( } 35 \text { times } \\
\text { exceeding the capability of MCTS) } \\
\text { - Good accuracy at high Hs value }\end{array}$ & $\begin{array}{l}\text { Restricted to a specific condition } \\
\text { of the wave height, particularly at } \\
\text { lower Hs values }\end{array}$ \\
\hline $\begin{array}{l}\text { Lambert L L.A., } \\
\text { Najafian G., } \\
\text { Copper J.E., } \\
\text { Abu Husain M.K., } \\
\text { Mohd Zaki N.I. } \\
\text { (2013) }\end{array}$ & $\begin{array}{l}\text { Efficient Threshold } \\
\text { Upcrossing (ETU) }\end{array}$ & $\begin{array}{l}\text { ETU method has an ability to be } \\
\text { up to } 3 \text { grades of magnitude better } \\
\text { than the MCTS method.ETU } \\
\text { method was slightly more stable } \\
\text { than the advanced ETS method. }\end{array}$ & $\begin{array}{l}\text { - Considered only for the } \\
\text { quasi-static structural responses. } \\
\text { Wave current and load } \\
\text { intermittency nearby the splash } \\
\text { area of the leg platform were } \\
\text { not considered }\end{array}$ \\
\hline $\begin{array}{l}\text { Mallahzadeh H., } \\
\text { Wang Y., Abu } \\
\text { Husain M.K., Mohd } \\
\text { Zaki N.I., Najafian G. } \\
\text { (2014) }\end{array}$ & $\begin{array}{l}\text { ETS-Relationship } \\
\quad \text { (ETS-RTS) }\end{array}$ & $\begin{array}{l}\text { ETS-RTS is a conceptual approach } \\
\text { that is employed to define the } \\
\text { short-term probability distribution } \\
\text { of extreme surface elevations for } \\
\text { the } 100 \text {-year without } \\
\text { comprehensive simulations }\end{array}$ & $\begin{array}{l}\text { - Constrained to uncomplicated } \\
\text { structures, testing only on single } \\
\text { leg structure and in terms of the } \\
\text { application, it was not considered } \\
\text { in current wave propagation and } \\
\text { intermittent loading, structure } \\
\text { nonlinearities and } \\
\text { dynamic responses }\end{array}$ \\
\hline $\begin{array}{l}\text { Gaspar B., Naess A., } \\
\text { Leira B.J., Soares C.G. } \\
(2014)\end{array}$ & $\begin{array}{l}\text { Montel Carlo Based } \\
\text { Method \& Finite } \\
\text { Element Structural } \\
\text { Models }\end{array}$ & $\begin{array}{l}\text { Applied to estimate the buckling } \\
\text { collapse strength reliability of a } \\
\text { ship hull girder stiffened panel } \\
\text { represented by non-linear of } \\
\text { finite element }\end{array}$ & $\begin{array}{l}\text { - } \quad \text { Limited to ship structure. } \\
\text { Estimating a reliability system } \\
\text { designed by a non-linear finite } \\
\text { element structural model }\end{array}$ \\
\hline $\begin{array}{l}\text { Aarland Y } \\
\quad(2015)\end{array}$ & $\begin{array}{l}\text { An equal area } \\
\text { principle (EAP) to } \\
\text { generate waves } \\
\text { instead of FFT } \\
\text { method }\end{array}$ & $\begin{array}{l}\text { EAP method overpredicts the } \\
\text { structural responses, meanwhile } \\
\text { the FFTrf and FFTrfa techniques } \\
\text { underestimate prediction. }\end{array}$ & $\begin{array}{l}\text { - Focusing this case study on } \\
\text { selection of } N \text {-samples (number of } \\
\text { wave component) }\end{array}$ \\
\hline $\begin{array}{l}\text { Johari M. B., } \\
\text { Abu Husain M.K. } \\
\qquad(2017)\end{array}$ & Optimization of ETS & $\begin{array}{l}\text { - Higher level of accuracy and } \\
\text { efficiency for estimating the } \\
\text { extreme offshore } \\
\text { structural response }\end{array}$ & - Inaccurate at low $H s$ value \\
\hline $\begin{array}{l}\text { Mukhlas N. A., } \\
\text { Mohd Zaki N.I., Abu } \\
\text { Husain M.K. } \\
\text { (2020) }\end{array}$ & $\begin{array}{l}\text { FMNS using } \\
\text { non-linear wave } \\
\text { theory }\end{array}$ & $\begin{array}{l}\text { Precisely estimating each wave } \\
\text { condition using non-Gaussian } \\
\text { stochastic modeling by } \\
\text { considering with and without } \\
\text { existence of current impact }\end{array}$ & $\begin{array}{l}\text { - Almost cover all the selected } \\
\text { criteria, except evaluating the } \\
\text { dynamic responses }\end{array}$ \\
\hline $\begin{array}{l}\text { Syed Ahmad, S.Z.A, } \\
\text { Abu Husain M.K., } \\
\text { Mohd Zaki N.I. } \\
\text { (2021) }\end{array}$ & $\begin{array}{l}\text { ETS-Regression } \\
\text { Procedure }\end{array}$ & $\begin{array}{l}\text { A more efficient and reliable } \\
\text { structural analysis approach by } \\
\text { (i) minimize extensive risk } \\
\text { integrity simulations, (ii) without } \\
\text { pass through several complicated } \\
\text { calculations processes applying } \\
\text { direct calculation procedures }\end{array}$ & $\begin{array}{l}\text { Excluding the analyzing the } \\
\text { dynamic structural responses }\end{array}$ \\
\hline
\end{tabular}

As noticed, an estimation approach based on the MCTS method was introduced recently in [140] with the intention of minimizing the computational time. For the application as an example, buckling collapse strength, Gaspar, et al. [141] proposed an MCTS method associated with a model of structural finite element process. With a nonlinear structural finite element process, the redundant computational time in order to assess the strength of such a vessel hull girder could be reduced. Regarding excessive samples of the wave, 
Aarland [142] proposes an alternative to FFT by presenting equal-area principle. This approach was implemented in order to prevent repeating the wave history with several thousands of wave components.

Johari [143] introduced a technique for an optimization of the ETS method. The optimization ETS method has been validated with the MCTS method by comparing the short-term probability distribution of extreme responses at several sea states with the appearance of current impacts. This study provides a better understanding of increasing the level of accuracy and efficiency for estimating the extreme offshore structural response. In order to get result with higher accuracy, a large number of groups (simulated response records) will systematically distribute probability of occurrence at the higher segment. Indeed, several enhanced simulated response records will decrease the level of efficiency of simulations.

Mukhlas [144] introduces a new model by combining the FMNS approach with a non-linear wave analysis for a more accurate outcome. This model was developed based on the advantage of the efficiency of the FMNS method in deriving the non-Gaussian responses. This invented FMNS method was known as the FMNS ${ }_{N L}$ model. For the recent findings, an ETS-Reg procedure was conceived to fulfil limitations of the ETS method, including to evaluate the level of efficiency. It is a combination of two methods of the conceptual ETS-RTS method and optimization of ETS method. Regarding conceptual ETSRTS method, the proposed model was developed based on the excellent correlation found between the extreme values of surface elevation (input) and their corresponding responses (output) $[138,139]$. Meanwhile, the suggested number of simulations equal to $N=260$ from the optimization of the ETS method would be used in the model development [143]. Hence, a simplified analysis-based time domain is introduced to overcome this issue by applying direct calculation procedures.

\section{Overall Review of the Probabilistic Domains on Offshore Structural Assessment}

Based on [20], the structural reliability analysis (SRA) and the quantitative risk analysis (QRA) are two categories of reliability assessments. The SRA intends to describe the POF due to the degradation mechanism (i.e., coating damage, corrosion, cracking, deformations, and changes in material properties) $[145,146]$. Also, the degradation process connected with the uncertainties should be considered in structural analysis. Meanwhile, the QRA is conducted based on decision-making to form a framework [147]. This framework is, along with approximations on the possibility of risks, endangering civilised (human) lives and health, assets, and commercial businesses [148].

Since the SRA approach is concerned with structure analysis, the study emphasizes that the probabilistic domain is a method for estimating the extreme structural responses as the POF value is calculated [149]. Under the SRA approach, several methods have been used to calculate the load impact on structures. Wave loading can be performed using two approaches, either applying a deterministic or probabilistic technique [32]. The deterministic approach would not take uncertainty into consideration during calculation implementation and corresponds only to normal (regular) waves [150]. Due to this restriction, another approach is introduced using probabilistic modelling on computing the wave estimation, which is to be more practical than the deterministic process when determining the hydrodynamic loadings of the structures [151].

As described in the previous Sections 3.1-3.3, three main types of domains such as probability, frequency, and time are categorized under the probabilistic approach. Each domain may have its benefits and drawbacks depending on the performance of method potential. Table 4 has summarized all the methods in probabilistic analysis with its corresponding output. The application of those methods was taken into account regarding the type of wave model, system structure be it evaluation either quasi-static or dynamic structures, statistical analysis (i.e., short-term or long-term), and the wave condition of current impacts. 
Table 4. Probabilistic domains in evaluating extreme responses.

\begin{tabular}{|c|c|c|c|c|c|c|c|c|c|c|}
\hline \multirow[t]{2}{*}{ Domains } & \multirow[t]{2}{*}{ Authors (Year) } & \multirow[t]{2}{*}{ Methods } & \multicolumn{2}{|c|}{$\begin{array}{l}\text { Wave } \\
\text { Model }\end{array}$} & \multicolumn{2}{|c|}{$\begin{array}{l}\text { Structural } \\
\text { Analysis }\end{array}$} & \multicolumn{2}{|c|}{$\begin{array}{l}\text { Time } \\
\text { Period }\end{array}$} & \multicolumn{2}{|c|}{$\begin{array}{l}\text { Current } \\
\text { Impact }\end{array}$} \\
\hline & & & $\mathbf{L}$ & NL & $\mathbf{R}_{\mathrm{QS}}$ & $\mathbf{R}_{\text {DYN }}$ & ST & LT & $\mathbf{P}$ & NP \\
\hline \multirow{3}{*}{ Probability } & Burrows R. $(1977 ; 1983)$ & Second and fourth statistical moment & / & & / & & / & / & & / \\
\hline & Najafian et. al. (2002) & Simple sampling techniques & & / & / & & / & & & / \\
\hline & Najafian (2007) & Principle component techniques & I & & I & & & & I & / \\
\hline \multirow{15}{*}{ Frequency } & Olagnon et. al. (1988) & $\begin{array}{l}\text { Nonlinear spectral calculation based on } \\
\text { Volterra kernels }\end{array}$ & & / & / & & & & & \\
\hline & Li et. al. (1995) & Volterra series (VS) & / & & & / & & & & / \\
\hline & Tognarelli et. al. (1997) & Volterra functional series & & / & / & & & & & \\
\hline & Naess and Pisano (1997) & $\begin{array}{l}\text { Exact computation of Probability } \\
\text { Density Functions }\end{array}$ & / & & & / & / & / & & / \\
\hline & Kareem et. al. (1998) & $\begin{array}{l}\text { Stokes' perturbation expansion } \\
\text { solution }\end{array}$ & / & / & / & / & / & & & / \\
\hline & Zheng and Liaw (2004) & Cumulant spectral analysis & / & & / & & & & & / \\
\hline & Ersdal (2005) & Stokes' analysis + USFOS & & / & / & & / & & / & / \\
\hline & Carassale and Kareem (2009) & $\begin{array}{l}\text { Improved version of Volterra } \\
\text { frequency-response functions }\end{array}$ & & / & & & & & & \\
\hline & Agarwal \& Manuel (2011) & $\begin{array}{l}\text { Second-order wave analysis + FAST } \\
\text { software }\end{array}$ & / & / & / & / & & & & \\
\hline & Norouzi and Nikolaidis (2012) & $\begin{array}{l}\text { Extended Probabilistic Re-analysis } \\
\text { method }\end{array}$ & / & & / & / & & & & / \\
\hline & Ebrahimian (2014) & Probability incremental wave analysis & & & & / & & & & \\
\hline & Chen (2014) & Second-order wave analysis & / & / & / & / & & & & \\
\hline & Natarajan (2014) & $\begin{array}{l}\text { Second-order wave analysis + HAWC2 } \\
\text { Software }\end{array}$ & / & / & / & / & & & & \\
\hline & Kim (2015) & NARX-based quadratic VS & / & & / & / & & & & / \\
\hline & Merigaud and Ringwood (2016) & Nonlinear frequency-domain (NLFD) & / & & / & & & & & / \\
\hline \multirow{5}{*}{ Time } & Orkin et. al. (1978) & Monte Carlo Time Simulation & / & & / & & & & & \\
\hline & Tromans et. al. (1991) & NewWave Theory & / & & / & & & & & \\
\hline & Taylor et. al. (1997) & Constrained time domain simulation & / & & / & & / & & / & \\
\hline & Cassidy et. al. (2001 and 2002) & Constrained New Wave (CNW) & / & / & / & / & / & / & / & / \\
\hline & Naess et. al. (2007) & Linear extrapolation technique & / & & / & & & & & \\
\hline \multirow{10}{*}{ Time } & $\begin{array}{l}\text { Najafian (2007) and Mohd Zaki } \\
\text { and Najafian (2008) }\end{array}$ & $\begin{array}{l}\text { Finite-memory nonlinear system } \\
\text { (FMNS) }\end{array}$ & / & & / & / & / & / & / & / \\
\hline & Abu Husain and Najafian (2010) & Efficient Time Simulation (ETS) & / & & / & / & / & / & / & / \\
\hline & Mohd Zaki et. al. (2013) & Modified FMNS & / & & / & / & / & / & / & / \\
\hline & Lambert et. al. (2013) & Efficient Threshold Upcrossing (ETU) & / & & / & & & & & \\
\hline & Mallazadeh et. al. (2014) & $\begin{array}{l}\text { ETS-Relationship Time Simulation } \\
\text { (ETS-RTS) }\end{array}$ & / & & / & & & & & \\
\hline & Gaspar et. al. (2014) & $\begin{array}{l}\text { Montel Carlo Based Metho-Finite } \\
\text { Element Models }\end{array}$ & / & & / & & & & & / \\
\hline & Aarland (2015) & $\begin{array}{l}\text { Preferring EAP to generate waves } \\
\text { instead of FFT method }\end{array}$ & / & & & & & & & / \\
\hline & Johari (2017) & Optimization of ETS & / & & / & & / & & / & / \\
\hline & Mukhlas et al. (2020) & FMNS using nonlinear wave theory & / & / & / & & / & / & / & / \\
\hline & Syed Ahmad et al. (2021) & ETS-Regression Procedure & / & & / & & / & / & / & / \\
\hline
\end{tabular}

Notes: L-Linear, NL—Nonlinear, RQS—Quasi-static response, RDYN-Dynamic response, ST—Short-term, LT—Long-term, P—Presence of current, NP-None Presence of current. 
Generally, the probability domain was used as a fundamental concept in the range of the first to the fourth statistical moment of their calculations [86,87]. Essentially, the probability domain is quite similar to the frequency domain in terms of efficiency, but the limited study shows that the level of accuracy is obviously far behind the frequency domain and time domain [152]. For that reason, there was not much effort that was expended in this domain to improve the previous methods. On the other hand, the frequency domain is what the industry is most looking toward, because it gives an accurate prediction with the efficient outcome that considers real structures $[153,154]$. In comparison to the time domain, the frequency domain does not take a long process of calculation in order to complete the full offshore structure assessment [155].

However, the frequency domain approach does not consider the nonlinearities in its calculation [102]. Due to that reason, the prediction of a specific critical condition was sometimes under-predicted or over-predicted, which gave inconsistent actual values [156,157]. Thus, to improve these prediction values, the probabilistic-based time domain was preferred. This is because the time domain considers all sort of nonlinearities in the calculation. Also, it can consider the randomness process from the wave, loads, and the effect of current and velocity kinematics, including the intermittency wave loadings around splash zones [158-161]. Thus, the time domain was a more accurate method compared to the probability and frequency domains [161-163].

\section{Conclusions}

- The fundamental principle of the design and analysis of offshore structures is that it enables their stability over design life to be maintained. It follows from the non-linear behaviourof fixed offshore platforms that they involve a considerable number of major uncertainties pertaining to the techniques of structural analysis, the mathematical models for the structural behaviour, the loading mechanism, and the response to the parameters concerned.

- The probabilistic approach has been shown to have several benefits compared to the deterministic approach. It offers, in particular, a clear framework for calibrating code design practices like the evolving load and resistance factor design (LRFD) methods. This will explain a decrease in the safety factors associated with the individual components through a clear reflection of the distinctive aspect of the wave environments and hydrodynamic response.

- There are three fields in which the response properties can be built on the basis of the probabilistic method;the probability, frequency, and time domain. The principal challenge in probabilistic analysis is the randomness of stochastic waves. An exact model for predicting extreme responses is important as awareness is necessary if the structural design of the offshore is to be optimised.

- With regard to design structural analysis, establishing a practicable technique that combines the latest short-term and long-term non-linear analysis methods with the conventional design wave methods seems desirable in a manner compatible with the reliability analysis.

- The long-term probability distribution, which is then required to analyse fatigue concerning the structural extreme during its service life, is needed to analyse the first excursion failure. It can be accomplished by transforming their respective short-term distributions into a long-term wave environment.

Author Contributions: S.Z.A.S.A. compiled the methods from previous researchers, analyzed the findings, and wrote the original draft paper; M.K.A.H. and N.I.M.Z. contributed to the review, discussion and verification on the results; N.A.M. extracted several methods based on the nonlinear wave modelling and also reviewed the paper; E.M.S. and N.U.A. shared about reliability analysis with industry experience perspective; G.N. contributed as a supervision. All authors have read and agreed to the published version of the manuscript. 
Funding: The paper is financially supported by the Ministry of Higher Education under FRGS (Registration Proposal No: FRGS/1/2018/TK01/UTM/02/15; FRGS/1/2019/TK01/UTM/02/17) and Universiti Teknologi Malaysia (Registration Proposal No: Q.K130000.2456.09G36; Q.K130000.2456.09G41) which is gratefully acknowledged.

Institutional Review Board Statement: Not applicable.

Informed Consent Statement: Not applicable.

Data Availability Statement: Not applicable.

Acknowledgments: The authors would like to acknowledge the support of the academic and industrial establishments they represent.

Conflicts of Interest: The authors declare no conflict of interest.

\section{Abbreviations}

$\begin{array}{ll}\text { API } & \text { American Petroleum Institute } \\ \text { API RP 2A } & \text { API Standard according to the Recommended Practice (RP) of 2A } \\ \text { CPU } & \text { Computer Processing Unit } \\ \text { EV R100 } & \text { 100-Year Extreme Responses } \\ \text { FFTrf and FFTrfa } & \text { Randomization of Wave Component Frequency } \\ \text { FFT } & \text { Fast Fourier Transform } \\ \text { HAWC2 } & \text { Horizontal Axis Wind Turbine Simulation Code 2nd Generation } \\ \text { PM } & \text { Pierson-Moskowitz Spectrum } \\ \text { POF } & \text { Probability of Failure } \\ \text { RSR } & \text { Reserve Strength Ratio } \\ \text { SACS } & \text { Structural Analysis Computer Software } \\ \text { SRA } & \text { Structural Reliability Analysis } \\ \text { USFOS } & \text { Ultimate Strength for Offshore Structural Software }\end{array}$

\section{Nomenclature}

$\begin{array}{lll}f_{p} & \text { peak frequency } & \mathrm{Hz} \\ G & \text { function of failure } & - \\ H & \text { wave height } & \mathrm{m} \\ H_{S} & \text { significant wave height } & \mathrm{m} \\ L & \text { load distribution (model) } & \mathrm{N} \text { or Nm } \\ n & \text { the smallest simulated extreme value } & - \\ N & \text { total number of simulation records (simulated responses) } & - \\ N_{a} & \text { annual average number of sample data } & - \\ P & \text { probability distribution (model) } & - \\ p_{x_{n}} & \text { cumulative probability of return periods } & - \\ R & \text { resistance distribution (model) } & \mathrm{N} \mathrm{or} \mathrm{Nm} \\ T & \text { wave period } & \mathrm{S} \\ T_{z} & \text { zero up-crossing wave period } & \mathrm{s} \\ T_{r} & \text { specific return periods } & -\end{array}$

\section{References}

1. Hübler, C.J. Efficient Probabilistic Analysis of Offshore Wind Turbines Based on Time-Domain Simulations. Ph.D. Thesis, Leibniz Universität, Hannover, Germany, 2019.

2. Folley, M. The Wave Energy Resource. In Handbook of Ocean Wave Energy; Pecher, A., Kofoed, J.P., Eds.; Springer International Publishing: Cham, Switzerland, 2017; pp. 43-79. [CrossRef]

3. Vanem, E. Joint Statistical Models for Significant Wave Height and Wave Period in a Changing Climate. Mar. Struct. 2016, 49, 180-205. [CrossRef]

4. Baarholm, G.S.; Haver, S.; Økland, O.D. Combining Contours of Significant Wave Height and Peak Period with Platform Response Distributions for Predicting Design Response. Mar. Struct. 2010, 23, 147-163. [CrossRef]

5. Vanem, E.; Fazeres-Ferradosa, T.; Rosa-Santos, P.; Taveira-Pinto, F. Statistical Description and Modelling of Extreme Ocean Wave Conditions. Proc. Inst. Civ. Eng.-Marit. Eng. 2019, 172, 124-132. [CrossRef] 
6. $\quad$ Lin, P. Numerical Modeling of Water Waves; CRC Press: Boca Raton, FL, USA, 2008.

7. Morooka, C.K.; Yokoo, I.H. Numerical Simulation and Spectral Analysis of Irregular Sea Waves. Int. J. Offshore Polar Eng. 1997, 7, ISOPE-97-07-3-189c.

8. Dimitrov, N. Comparative Analysis of Methods for Modelling the Short-Term Probability Distribution of Extreme Wind Turbine Loads. Wind Energy 2016, 19, 717-737. [CrossRef]

9. Benstock, D.; Cegla, F. Extreme Value Analysis (EVA) of Inspection Data and Its Uncertainties. NDT E Int. 2017, 87, 68-77. [CrossRef]

10. Raheem, S.E.A. Nonlinear Response of Fixed Jacket Offshore Platform Under Structural and Wave Loads. Coupled Syst. Mech. 2013, 2, 111-126. [CrossRef]

11. Abdel Raheem, S.E. Nonlinear behaviour of steel fixed offshore platform under environmental loads. Ships Offshore Struct. 2016, 11, 1-15. [CrossRef]

12. Petrauskas, C.; Heideman, J.C.; Berek, E.P. Extreme Wave-Force Calculation Procedure for 20th Edition of API-RP-2A. In Proceedings of the Offshore Technology Conference, Houston, TX, USA, 3-6 May 1993; p. 11.

13. Nallayarasu, S. Offshore Structures-Analisys and Design. Ph.D. Thesis, Indian Instritute of Technology Madras, Chennai, India, 1981.

14. Stewart, G. Reassessment of Fixed Offshore Structures. Encycl. Marit. Offshore Eng. 2017, 1-17. [CrossRef]

15. Bea, R.G. Structural Reliability: Design and Requalification of Offshore Platforms. In Proceedings of the Reliability of Offshore Operations, Proceedings, International Workshop, Building and Fire Research Laboratory, Berkeley, CA, USA, 1-3 April 1992; pp. $41-67$.

16. Sadeghi, K.; Dilek, H. An Introduction to the Design of Offshore Structures. Acad. Res. Int. 2019, 10, $19-27$.

17. Wei, K.; Liu, Q.; Qin, S. Nonlinear Assessment of Offshore Steel Trestle Subjected to Wave and Current Loads. Ships Offshore Struct. 2019, 15, 479-491. [CrossRef]

18. Kharade, A.; Kapadiya, S. Offshore Engineering: An Overview of Types and Loadings on Structures. Int. J. Struct. Civ. Eng. Res. 2014, 3, 16-28.

19. El-Reedy, M.A. Offshore Structures: Design, Construction and Maintenance; Gulf Professional Publishing: Houston, TX, USA, 2019.

20. Melchers, R.E.; Beck, A.T. Structural Reliability Analysis and Prediction; John Wiley \& Sons: Hoboken, NJ, USA, 2018.

21. Chandrasekaran, S. Environmental forces. In Dynamic Analysis and Design of Offshore Structures; Springer: Berlin/Heidelberg, Germany, 2018; pp. 63-125.

22. Connor, J.J.; Faraji, S. Fundamentals of Structural Engineering, 2nd ed.; Springer: Berlin/Heidelberg, Germany, 2016.

23. Slåke, T. Analysis of Jacket Type Fixed Platforms-Effect of Various Mass Modelling Approaches for Topsides on Structural Response. Master's Thesis, University of Stavanger, Stavanger, Norway, 2016.

24. Kolios, A.; Brennan, F. Reliability Based Design of Novel Offshore Structures. In Proceedings of the 3rd International Conference on Integrity, Chengdu, China, 20-24 July 2009.

25. Hørte, T.; Sigurdsson, G. On the Application of Structural Reliability Analysis. In Proceedings of the 36th International Conference on Ocean, Offshore and Arctic Engineering, Trondheim, Norway, 25-30 June 2017.

26. Moan, T. Safety of Offshore Structures; National University of Singapore: Singapore, 2005.

27. Wouts, M.; van der Graaf, J.; Vrouwenvelder, A. Fatigue Reliability Analyses of Fixed Offshore Structures. In Proceedings of the European Petroleum Conference, London, UK, 16-19 October 1988.

28. Mukherjee, D.; Mahadevan, S. Reliability-based Structural Design. In Proceedings of the Annual Reliability and Maintainability Symposium, Washington, DC, USA, 16-19 January 1995; pp. 207-212.

29. Jiang, Z.; Hu, W.; Dong, W.; Gao, Z.; Ren, Z. Structural reliability analysis of wind turbines: A review. Energies 2017, 10, 2099. [CrossRef]

30. San Tint, A. Reliability Analysis of the Final Design of a Fixed Offshore Jacket. Master's Thesis, Asian Institute of Technology, Khlong Nueng, Thailand, 2015.

31. Ayyub, B.M.; McCuen, R.H. Probability, Statistics, and Reliability for Engineers and Scientists; CRC Press: Boca Raton, FL, USA, 2016.

32. Lotsberg, I.; Sigurdsson, G.; Fjeldstad, A.; Moan, T. Probabilistic Methods for Planning of Inspection for Fatigue Cracks in Offshore Structures. Mar. Struct. 2016, 46, 167-192. [CrossRef]

33. Mat Soom, E.; Abu Husain, M.K.; Mohd Zaki, N.I.; Azman, N.U.; Najafian, G. Reliability-Based Design and Assessment for Lifetime Extension of Ageing Offshore Structures. In Proceedings of the 35th International Conference on Ocean, Offshore and Arctic Engineering, Busan, Korea, 19-24 June 2016; p. V003T002A044.

34. Mat Soom, E.; Abu Husain, M.K.; Mohd Zaki, N.I.; Mohd Nor, K.; Ayob, M.S.; Najafian, G. Lifetime Extension of Ageing Offshore Structures by Global Ultimate Strength Assessment (GUSA). Malays. J. Civ. Eng. 2018, 30, 1. [CrossRef]

35. Zeinoddini, M.; Golpour, H.; Khalili, H.; Matin Nikoo, H.; Ahmadi, I. Sensitivity Analysis of Selected Random Variables of Existing Offshore Jacket Structures in Persian Gulf. Int. J. Coast. Offshore Eng. 2017, 5, 7-16.

36. Mirzadeh, J.; Kimiaei, M.; Cassidy, M.J. A Framework to Efficiently Calculate the Probability of Failure of Dynamically Sensitive Structures in A Random Sea. Ocean. Eng. 2015, 110, 215-226. [CrossRef]

37. Mat Soom, E.; Abu Husain, M.K.; Mohd Zaki, N.I.; Azman, N.U.; Structural Reliability Analysis for Fixed Offshore Platforms. Jurutera 2019. Available online: http:/ /103.86.130.60/xmlui/bitstream/handle/123456789/62313/Structural\%20reliability\%20 analysis\%20for\%20fixed\%20offshore\%20platforms.pdf?sequence=1 (accessed on 7 September 2021). 
38. van Os, J.; Caires, S.; van Gent, M. Guidelines for Metocean Data Analysis. In Proceedings of the Twenty-First International Offshore and Polar Engineering Conference, Beijing, China, 20-25 June 2010.

39. Li, P.; Zhu, Q.; Zhou, C.; Li, L.; Li, H. Metocean Design Criteria Considerations in South China Sea by Adopting Multivariate Extreme Value Theory. In Proceedings of the 36th International Conference on Ocean, Offshore and Arctic Engineering, Trondheim, Norway, 25-30 June 2017.

40. Cremona, C. Structural Performance: Probability-Based Assessment; John Wiley \& Sons: Hoboken, NJ, USA, 2012.

41. Czujko, J.; Bayatfar, A.; Smith, M.; Xu, M.; Wang, D.; Lützen, M.; Saad-Eldeen, S.; Yanagihara, D.; Notaro, G.; Qian, X.; et al. Committee III. 1: Ultimate Strength. In Proceedings of the 20th International Ship and Offshore Structures Congress (ISSC 2018), Liege, Belgium; Amsterdam, The Netherlands, 9-14 September 2018; pp. 381-390.

42. Fjeld, S. Reliability of Offshore Structures. J. Pet. Technol. 1978, 30, 1486-1496. [CrossRef]

43. Chen, J.; Gilbert, R.B. Offshore Pile System Model Biases and Reliability. Georisk Assess. Manag. Risk Eng. Syst. Geohazards 2017, 11, 55-69. [CrossRef]

44. Low, B. Insights from Reliability-Based Design to Complement Load And Resistance Factor Design Approach. J. Geotech. Geoenvironmental Eng. 2017, 143, 04017089. [CrossRef]

45. Stewart, G.; Manzocchi, M. Recent Developments in Probabilistic Pushover Models for The Reliability Re-Assessment of Fixed Offshore Structures. Saf. Reliab. 2018, 38, 3-31. [CrossRef]

46. Mat Soom, E. Efficient Load Coefficient Method for Structural Reliability Assessment of Ageing Offshore Platforms. Ph.D. Thesis, Universiti Teknologi Malaysia, Johor Bahru, Malaysia, 2018.

47. Nava-Viveros, I.; Heredia-Zavoni, E. Assessment of Statistical Parameter Uncertainty in The Reliability Analysis of Jacket Platforms. In Proceedings of the Ocean Engineering, Hong Kong, China, 13-14 October 2016; pp. 370-379.

48. Shittu, A.A.; Mehmanparast, A.; Wang, L.; Salonitis, K.; Kolios, A. Comparative study of structural reliability assessment methods for offshore wind turbine jacket support structures. Appl. Sci. 2020, 10, 860. [CrossRef]

49. Mat Soom, E.; Abu Husain, M.K.; Mohd Zaki, N.I.; Azman, N.U. A Reliable Approach for Fixed Offshore Structures Probability of Failure Determination. Int. J. Adv. Res. Eng. Technol. (IJARET) 2020, 11, 469-475.

50. API. Recommended Practice for Planning, Designing and Constructing Fixed Offshore Platforms—Working Stress Design; American Petroleum Institute: Washington, DC, USA, 1993.

51. Şen, Z. Probability and Statistical Methods. In Flood Modeling, Prediction and Mitigation; Springer: Berlin/Heidelberg, Germany, 2018; pp. 245-301.

52. Zhang, B.; Shang, Z.-Q.; Wang, T.; Wang, Z. Hydrodynamic Load Analysis and Experimental Study of Grouting Clamp under Wave and Ocean Current. J. Mar. Sci. Eng. 2020, 8, 512. [CrossRef]

53. Zhao, Y.; Guan, C.; Bi, C.; Liu, H.; Cui, Y. Experimental investigations on hydrodynamic responses of a semi-submersible offshore fish farm in waves. J. Mar. Sci. Eng. 2019, 7, 238. [CrossRef]

54. Zhang, J.; Benoit, M.; Kimmoun, O.; Chabchoub, A.; Hsu, H.-C. Statistics of Extreme Waves in Coastal Waters: Large Scale Experiments and Advanced Numerical Simulations. Fluids 2019, 4, 99. [CrossRef]

55. Kareem, A.; Kijewski, T. Time-Frequency Analysis of Wind Effects On Structures. J. Wind. Eng. Ind. Aerodyn. 2002, 90, 1435-1452. [CrossRef]

56. Phillips, O.M. The Equilibrium Range in The Spectrum of Wind-Generated Waves. J. Fluid Mech. 1958, 4, 426-434. [CrossRef]

57. Faltinsen, O.M. Sea Loads on Ships and Offshore Structures; Cambridge University Press: New York, NY, USA, 1990 ; Volume 1.

58. Colagrossi, A.; Landrini, M. Numerical simulation of interfacial flows by smoothed particle hydrodynamics. J. Comput. Phys. 2003, 191, 448-475. [CrossRef]

59. Bateman, W.J.; Swan, C.; Taylor, P.H. On The Efficient Numerical Simulation of Directionally Spread Surface Water Waves. J. Comput. Phys. 2001, 174, 277-305. [CrossRef]

60. Zheng, X.Y.; Moan, T.; Quek, S.T. Numerical Simulation of Non-Gaussian Wave Elevation and Kinematics Based on TwoDimensional Fourier Transform. In Proceedings of the 25th International Conference on Offshore Mechanics and Arctic Engineering, Hamburg, Germany, 4-9 June 2006; pp. 7-16.

61. Abu Husain, M.K.; Mohd Zaki, N.I.; Johari, M.B.; Najafian, G. Extreme Response Prediction for Fixed Offshore Structures by Monte Carlo Time Simulation Technique. In Proceedings of the 35th International Conference on Ocean, Offshore and Arctic Engineering, Busan, Korea, 19-24 June 2016; p. V003T002A037.

62. Najafian, G. Local Hydrodynamic Force Coefficients from Field Data and Probabilistic Analysis of Offshore Structures Exposed to Random Wave Loading. Ph.D. Thesis, University of Liverpool, Liverpool, UK, 1991.

63. Azarhoushang, A. Dynamic Response of Fixed Offshore Platforms to Environmental Loads. Master's Thesis, Curtin University of Technology, Perth, Australia, 2010.

64. He, Y.; Bi, J.; Haritos, N. Hydrodynamic forces and interactions of multiple circular cylindrical structure-fluid-soil systems. Appl. Ocean Res. 1992, 14, 231-239. [CrossRef]

65. Schmucker, D.G. Near-Failure Behavior of Jacket-Type Offshore Platforms in the Extreme Wave Environment. Ph.D. Thesis, Stanford University, Stanford, CA, USA, 1997.

66. Iraninejad, B. Dynamic Analysis of Fixed Offshore Platforms Subject to Nonlinear Hydrodynamic Loading. Ph.D. Thesis, University of California, Berkeley, CA, USA, 1989.

67. Ang, A.H.-S.; Tang, W.H. Probability Concepts in Engineering Planning and Design; John Wiley \& Sons: Hoboken, NJ, USA, 1984. 
68. Najafian, G.; Burrows, R.; Tickell, R. A Review of the Probabilistic Description of Morison Wave Loading and Response of Fixed Offshore Structures. J. Fluids Struct. 1995, 9, 585-616. [CrossRef]

69. Wang, Y.; Mallahzadeh, H.; Abu Husain, M.K.; Mohd Zaki, N.I.; Najafian, G. Probabilistic Modelling of Extreme Offshore Structural Response Due to Random Wave Loading. In Proceedings of the 32nd International Conference on Ocean, Offshore and Arctic Engineering, Nantes, France, 9-14 June 2013; p. V02BT02A007.

70. Bitner-Gregersen, E.M.; Dong, S.; Fu, T.; Ma, N.; Maisondieu, C.; Miyake, R.; Rychlik, I. Sea State Conditions for Marine Structures' Analysis and Model Tests. Ocean Eng. 2016, 119, 309-322. [CrossRef]

71. Taylor, R.E.; Jefferys, E. Variability of Hydrodynamic Load Predictions for A Tension Leg Platform. Ocean Eng. 1986, 13, 449-490. [CrossRef]

72. Suyuthi, A.; Haver, S.K. Extreme Loads Due to Wave Breaking Against Platform Column. In Proceedings of the Nineteenth International Offshore and Polar Engineering Conference, Osaka, Japan, 21-26 July 2009.

73. Ha, Y.-J.; Kim, K.-H.; Nam, B.W.; Hong, S.Y. Experimental Study of Wave Impact Loads on Circular Cylinder by Breaking Waves. In Proceedings of the 28th International Ocean and Polar Engineering Conference, Sapporo, Japan, 10-15 June 2018.

74. Karadeniz, H. Uncertainty Modeling in The Fatigue Reliability Calculation of Offshore Structures. Reliab. Eng. Syst. Saf. 2001, 74, 323-335. [CrossRef]

75. Reid, S.; Naess, A. Influence on Structural Reliability of Uncertain Extreme Value Estimates. In Proceedings of the 36th International Conference on Ocean, Offshore and Arctic Engineering, Trondheim, Norway, 25-30 June 2017; p. V009T012A037.

76. Moon, M.-Y.; Kim, H.-S.; Lee, K.; Park, B.; Choi, K. Uncertainty Quantification and Statistical Model Validation for an Offshore Jacket Structure Panel Given Limited Test Data and Simulation Model. Struct. Multidiscip. Optim. 2020, 61, 2305-2318. [CrossRef]

77. Oumeraci, H.; Kortenhaus, A.; Allsop, W.; de Groot, M.; Crouch, R.; Vrijling, H.; Voortman, H. Probabilistic Design Tools for Vertical Breakwaters; CRC Press: Boca Raton, FL, USA, 2001.

78. Bruserud, K.; Haver, S. Uncertainties in Current Measurements in The Northern North Sea. J. Atmos. Ocean. Technol. 2017, 34, 855-876. [CrossRef]

79. Wu, Y.-T.; Burnside, O.; Cruse, T. Probabilistic Methods for Structural Response Analysis. In Proceedings of the ASME/SES Applied Mechanics and Engineering Sciences Conference, San Antonio, TX, USA, 20-22 June 1988.

80. Kirchsteiger, C. On The Use of Probabilistic and Deterministic Methods in Risk Analysis. J. Loss Prev. Process. Ind. 1999, 12, 399-419. [CrossRef]

81. Sundararajan, C.R. Probabilistic Structural Mechanics Handbook: Theory and Industrial Applications; Springer Science \& Business Media: Berlin/Heidelberg, Germany, 2012.

82. Holmes, P.; Tickell, R.; Burrows, R. Prediction of Long-Term Wave Loading On Offshore Structures. UK Rep. Dep. Energy 1978, 7823-7824. Available online: https:/ / xueshu.baidu.com/usercenter/paper/show?paperid=b22eaf3499bdc560735a45667483ac4 0\&site=xueshu_se (accessed on 7 September 2021).

83. Price, R. A Useful Theorem for Nonlinear Devices Having Gaussian Inputs. IRE Trans. Inf. Theory 1958, 4, 69-72. [CrossRef]

84. Tickell, R. Continuous Random Wave Loading on Structural Members. Structural Engineer 1977, 55, $209-222$.

85. Papoulis, A.; Pillai, S.U. Probability, Random Variables, and Stochastic Processes; Tata McGraw-Hill Education: New York, NY, USA, 2002.

86. Burrows, R. Probabilistic Description of the Response of Offshore Structures to Random Wave Loading. In Mechanics of Wave Induced Forces on Cylinders; Shaw, T.L., Ed.; Pitman Publishing: London, UK, 1979; pp. 577-595.

87. Burrows, R. Quasi-Static Response of Offshore Structures Using Probabilistic Methods. Appl. Math. Model. 1977, 1, 325-332. [CrossRef]

88. Burrows, R. Expected Value Analysis for the Quasi-Static Response of Offshore Structures. Appl. Math. Model. 1983, 7, 317-328. [CrossRef]

89. Najafian, G.; Burrows, R.; Tickell, R. Probabilistic Description of the Response of Offshore Structures to Wave Loading Via Random Sampling Technique. In Proceedings of the Ninth International Offshore and Polar Engineering Conference, Brest, France, 30 May-4 June 1999.

90. Najafian, G.; Burrows, R.; Tickell, R.G.; Metcalfe, A.V. Higher-Order Statistical Moments of Wave-Induced Response of Offshore Structures Via Efficient Sampling Techniques. In Proceedings of the Twelfth International Offshore and Polar Engineering Conference, Kitakyushu, Japan, 26-31 May 2002.

91. Najafian, G. Derivation of Statistical Properties of Wave-Induced Offshore Structural Response by Principal Component Technique. Ocean Eng. 2007, 34, 987-999. [CrossRef]

92. Glisic, A.; Ferraz, G.T. Stochastic Variables in Modelling of the Wave Loads on Offshore Wind Turbine Structures. In Proceedings of the CESARE'17 International Conference, Dead Sea, Jordan, 3-8 May 2017.

93. Ameryoun, H.; Schoefs, F.; Barillé, L.; Thomas, Y. Stochastic Modeling of Forces on Jacket-Type Offshore Structures Colonized by Marine Growth. J. Mar. Sci. Eng. 2019, 7, 158. [CrossRef]

94. Ziegler, L.; Voormeeren, S.; Schafhirt, S.; Muskulus, M. Design Clustering of Offshore Wind Turbines Using Probabilistic Fatigue Load Estimation. Renew. Energy 2016, 91, 425-433. [CrossRef]

95. Goryunova, M.; Kuleshova, L.; Khakimova, A. Application of Signal Analysis for Diagnostics. In Proceedings of the International Conference on Industrial Engineering, Applications and Manufacturing (ICIEAM), Petersburg, Russia, 16-19 May 2017; pp. 1-5.

96. Olagnon, M.; Prevosto, M.; Joubert, P. Nonlinear Spectral Computation of the Dynamic Response of a Single Cylinder. J. Offshore Mech. Arct. Eng. 1988, 110, 278-281. [CrossRef] 
97. Li, X.-M.; Quek, S.-T.; Koh, C.-G. Stochastic Response of Offshore Platforms by Statistical Cubicization. J. Eng. Mech. 1995, 121, 1056-1068. [CrossRef]

98. Tognarelli, M.A.; Zhao, J.; Rao, K.B.; Kareem, A. Equivalent Statistical Quadratization and Cubicization for Nonlinear Systems. J. Eng. Mech. 1997, 123, 512-523. [CrossRef]

99. Bendat, J.S. Nonlinear System Analysis and Identification from Random Data; Wiley-Interscience: Hoboken, NJ, USA, 1990.

100. Bouyssy, V.; Rackwitz, R. Polynomial Approximation of Morison Wave Loading. J. Offshore Mech. Arct. Eng. 1997, 119, 30-36. [CrossRef]

101. Naess, A.; Pisano, A. Frequency Domain Analysis of Dynamic Response of Drag Dominated Offshore Structures. Appl. Ocean Res. 1997, 19, 251-262. [CrossRef]

102. Kareem, A.; Hsieh, C.; Tognarelli, M. Frequency-Domain Analysis of Offshore Platform in Non-Gaussian Seas. J. Eng. Mech. 1998, 124, 668-683. [CrossRef]

103. Zheng, X.; Liaw, C. Response Cumulant Analysis of a Linear Oscillator Driven by Morison Force. Appl. Ocean Res. 2004, 26, 154-161. [CrossRef]

104. Ersdal, G. Assessment of Existing Offshore Structures for Life Extension. Ph.D. Thesis, University of Stavanger, Stavanger, Norway, 2005.

105. Puskar, F.; Spong, R.; Ku, A.; Gilbert, R.; Choi, Y. Assessment of fixed offshore platform performance in Hurricane Ivan. In Proceedings of the Offshore Technology Conference, Houston, TX, USA, 1-4 May 2006.

106. Marzocca, P.; Nichols, J.; Milanese, A.; Seaver, M.; Trickey, S. Second-order spectra for quadratic nonlinear systems by Volterra functional series: Analytical description and numerical simulation. Mech. Syst. Signal Process. 2008, 22, 1882-1895. [CrossRef]

107. Carassale, L.; Kareem, A. Modeling Nonlinear Systems by Volterra Series. J. Eng. Mech. 2009, 136, 801-818. [CrossRef]

108. Agarwal, P.; Manuel, L. Incorporating irregular nonlinear waves in coupled simulation and reliability studies of offshore wind turbines. Appl. Ocean Res. 2011, 33, 215-227. [CrossRef]

109. Norouzi, M.; Nikolaidis, E. Efficient Estimation of First Excursion Failure of Dynamic Systems by Probabilistic Re-analysis. In Proceedings of the 12th AIAA Aviation Technology Integration and Operations (ATIO) Conference and 14th AIAA/ISSMO Multidisciplinary Analysis and Optimization Conference, Indianapolis, IN, USA, 17-19 September 2012; p. 5664.

110. Ebrahimian, H.; Jalayer, F.; De Dominicis, R.; Manfredi, G. Probability-Based Assessment of Jacket-Type Offshore. In Proceedings of the 7th EUROpean Conference on STEEL and Composite Structures (EUROSTEEL), Naples, Italy, 10-12 September 2014.

111. Chen, J. Non-linear Wave Loads on Offshore Wind Support Structure. Master's Thesis, Norwegian University of Science and Technology, Trondheim, Norway, 2014.

112. Alberello, A.; Chabchoub, A.; Gramstad, O.; Babanin, A.; Toffoli, A. Statistics of Wave Orbital Velocities in Random Directional Sea States. Statistics 2014, 8, 11.

113. Kim, Y. Prediction of The Dynamic Response of a Slender Marine Structure Under an Irregular Ocean Wave Using the NARXBased Quadratic Volterra Series. Appl. Ocean Res. 2015, 49, 42-56. [CrossRef]

114. Saeedfar, S.; Abd Wahab, A. An Evaluation of the Depth of Similarity between Linear and Non-linear Wave Theories. In Proceedings of the 3rd International Conference on Water Resources, Sanya, China, 2-4 December 2011; pp. 1-11.

115. Mérigaud, A.; Ringwood, J.V. A Nonlinear Frequency-Domain Approach for Numerical Simulation of Wave Energy Converters. IEEE Trans. Sustain. Energy 2017, 9, 86-94. [CrossRef]

116. Kühn, M.J. Dynamics and Design Optimisation of Offshore Wind Energy Conversion Systems; DUWIND, Delft University Wind Energy Research Institute: Delft, The Netherlands, 2001.

117. Van Der Tempel, J. Design of Support Structures for Offshore Wind Turbines. Ph.D. Thesis, Delft University of Technology, Delft, The Netherlands, 2006.

118. Seidel, M. Wave Induced Fatigue Loads: Insights from Frequency Domain Calculations. Stahlbau 2014, 83, 535-541. [CrossRef]

119. Kang, H.; Kim, M. Time-Domain Hydroelastic Analysis with Efficient Load Estimation for Random Waves. Int. J. Nav. Archit. Ocean Eng. 2017, 9, 266-281. [CrossRef]

120. Mohammadi, S.; Galgoul, N.; Starossek, U. Comparison of Time Domain and Spectral Fatigue Analyses of an Offshore Jacket Structure. In Proceedings of the 26th International Ocean and Polar Engineering Conference, Rhodes, Greece, 26 June-2 July 2016.

121. Orkin, G.L.; Folck, R.L.; Startzman, R.A. Monte Carlo Simulation of Offshore Terminal Operations. In Proceedings of the SPE California Regional Meeting, San Francisco, CA, USA, 12-14 April 1978.

122. Nikolaidis, E.; Mourelatos, Z.P.; Pandey, V. Design Decisions under Uncertainty with Limited Information: Structures and Infrastructures Book Series; CRC Press: Boca Raton, FL, USA, 2011; Volume 7.

123. Tromans, P.S.; Anaturk, A.R.; Hagemeijer, P. A New Model for The Kinematics of Large Ocean Waves-Application as a Design Wave. In Proceedings of the First International Offshore and Polar Engineering Conference, Edinburgh, UK, 11-16 August 1991.

124. Bar-Avi, P. Nonlinear Dynamics of Compliant Offshore Structures; Routledge: Oxfordshire, UK, 2017.

125. Fedele, F.; Brennan, J.; De León, S.P.; Dudley, J.; Dias, F. Real World Ocean Rogue Waves Explained Without the Modulational Instability. Sci. Rep. 2016, 6, 27715. [CrossRef]

126. Sclavounos, P.D.; Zhang, Y.; Ma, Y.; Larson, D.F. Offshore Wind Turbine Nonlinear Wave Loads and Their Statistics. J. Offshore Mech. Arct. Eng. 2019, 141, 031904. [CrossRef]

127. Cassidy, M.; Taylor, R.E.; Houlsby, G. Analysis of Jack-Up Units Using a Constrained Newwave Methodology. Appl. Ocean. Res. 2001, 23, 221-234. [CrossRef] 
128. Cassidy, M.; Taylor, P.; Taylor, R.E.; Houlsby, G. Evaluation of Long-Term Extreme Response Statistics of Jack-Up Platforms. Ocean Eng. 2002, 29, 1603-1631. [CrossRef]

129. Naess, A.; Gaidai, O.; Haver, S. Efficient Estimation of Extreme Response of Drag-Dominated Offshore Structures by Monte Carlo Simulation. Ocean Eng. 2007, 34, 2188-2197. [CrossRef]

130. Najafian, G. Application of System Identification Techniques in Efficient Modelling of Offshore Structural Response. Part I: Model Development. Appl. Ocean Res. 2007, 29, 1-16. [CrossRef]

131. Najafian, G. Application of System Identification Techniques in Efficient Modelling of Offshore Structural Response. Part II: Model Validation. Appl. Ocean Res. 2007, 29, 17-36. [CrossRef]

132. Najafian, G.; Zaki, N. Finite-Memory Nonlinear System Modelling of Offshore Structures. In Proceedings of the 27th International Conference on Offshore Mechanics and Arctic Engineering, Estoril, Portugal, 15-20 June 2008; pp. 743-752.

133. Mohd Zaki, N.I.; Abu Husain, M.K.; Wang, Y.; Najafian, G. Short-term distribution of the extreme values of offshore structural response by modified finite-memory nonlinear system modeling. In Proceedings of the 32nd International Conference on Ocean, Offshore and Arctic Engineering, Nantes, France, 9-14 June 2013.

134. Abu Husain, M.K.; Najafian, G. An Efficient Monte Carlo Simulation Technique for Derivation of the Probability Distribution of the Extreme Values of Offshore Structural Response. In Proceedings of the 29th International Conference on Ocean, Offshore and Arctic Engineering, Shanghai, China, 6-11 June 2010; pp. 369-375.

135. Lambert, L.A.; Najafian, G.; Cooper, J.E.; Abu Husain, M.K.; Mohd Zaki, N.I. Efficient Estimation of Offshore Structural Response Based on Threshold Upcrossing Rates. In Proceedings of the 32nd International Conference on Ocean, Offshore and Arctic Engineering, Nantes, France, 9-14 June 2013; pp. 9-14.

136. Mallahzadeh, H.; Wang, Y.; Abu Husain, M.K.; Mohd Zaki, N.I.; Najafian, G. Efficient Derivation of the Probability Distribution of Extreme Responses Due to Random Wave Loading from The Probability Distribution of Extreme Surface Elevations. In Proceedings of the 32nd International Conference on Ocean, Offshore and Arctic Engineering, Nantes, France, 9-14 June 2013.

137. Mallahzadeh, H.; Wang, Y.; Abu Husain, M.K.; Mohd Zaki, N.I.; Najafian, G. Accurate Estimation of The 100-Year Responses from The Probability Distribution of Extreme Surface Elevations. In Proceedings of the 33rd International Conference on Ocean, Offshore and Arctic Engineering, San Francisco, CA, USA, 8-13 June 2014; pp. 8-13.

138. Mallahzadeh, H.; Najafian, G.; Husain, M.; Zaki, N.M. Derivation of Probability Distribution of Extreme Offshore Structural Response due to Combined Wave and Current Loading from the Probability Distribution of Extreme Surface Elevations. In Proceedings of the 7th International ASRANet Conference, Glasgow, UK, 18-20 August 2014.

139. Naess, A.; Leira, B.; Batsevych, O. System Reliability Analysis by Enhanced Monte Carlo Simulation. Struct. Saf. 2009, 31, 349-355. [CrossRef]

140. Gaspar, B.; Naess, A.; Leira, B.J.; Soares, C.G. System Reliability Analysis by Monte Carlo Based Method and Finite Element Structural Models. J. Offshore Mech. Arct. Eng. 2014, 136, 031603. [CrossRef]

141. Aarland, Y. Time-Domain Simulation of Marine Structures in Irregular Seas. Master's Thesis, Norwegian University of Science and Technology, Trondheim, Norway, 2015.

142. Johari, M.B. Optimisation Of Efficient Time Simulation Method For The Prediction Of Extreme Offshore Structural Response. Master's Thesis, Universiti Teknologi Malaysia, Johor Bahru, Malaysia, 2016.

143. Mukhlas, N.A. Efficient Derivation of Extreme Non-Gaussian Stochastic Structural Response. Ph.D. Thesis, Universiti Teknologi Malaysia, Johor Bahru, Malaysia, 2020.

144. Zakikhani, K.; Nasiri, F.; Zayed, T. A Review of Failure Prediction Models for Oil and Gas Pipelines. J. Pipeline Syst. Eng. Pract. 2020, 11, 03119001. [CrossRef]

145. Zhao, Y.; Dong, S.; Jiang, F.; Soares, C.G. System Reliability Analysis of an Offshore Jacket Platform. J. Ocean Univ. China 2020, 19, 47-59. [CrossRef]

146. Li, X.; Chen, G.; Zhu, H. Quantitative Risk Analysis On Leakage Failure of Submarine Oil and Gas Pipelines Using Bayesian Network. Process Saf. Environ. Prot. 2016, 103, 163-173. [CrossRef]

147. He, R.; Li, X.; Chen, G.; Wang, Y.; Jiang, S.; Zhi, C. A Quantitative Risk Analysis Model Considering Uncertain Information. Process Saf. Environ. Prot. 2018, 118, 361-370. [CrossRef]

148. Moan, T. Life Cycle Structural Integrity Management of Offshore Structures. Struct. Infrastruct. Eng. 2018, 14, 911-927. [CrossRef]

149. Helder, J.A.; Bunnik, T. Deterministic Breaking Wave Simulation for Offshore Applications. In Proceedings of the SNAME 21st Offshore Symposium, Houston, TX, USA, 16 February 2016.

150. Klein, M.; Dudek, M.; Clauss, G.F.; Ehlers, S.; Behrendt, J.; Hoffmann, N.; Onorato, M. On the Deterministic Prediction of Water Waves. Fluids 2020, 5, 9. [CrossRef]

151. Burrows, R. Wave Loading on Offshore Structures: A Probabilistic Approach. Ph.D. Thesis, University of Liverpool, Liverpool, $\mathrm{UK}, 1982$.

152. Jurado, A.M.P.; Borg, M.; Bredmose, H. An Efficient Frequency-Domain Model for Quick Load Analysis of Floating Offshore Wind Turbines. Wind Energy Sci. 2018, 3, 693-712. [CrossRef]

153. Ziegler, L.S. Probabilistic Estimation of Fatigue Loads on Monopile-based Offshore Wind Turbines. Master's Thesis, Norwegian University of Science and Technology, Trondheim, Norway, 2015. 
154. Abhishek, A.; Metrikine, A.V.; Male, P.v.d.; Dalen, K.N.v. Reduction of Fatigue Computational Time for Offshore Wind Turbine Jacket Foundations: Investigation of Lumping Methods for Correlated Wind-Wave Data and Frequency-Domain Approach. Master's Thesis, Delft University of Technology, Delft, The Netherlands, 2018.

155. Moan, T.; Zheng, X.Y.; Quek, S.T. Frequency-Domain Analysis of Non-Linear Wave Effects On Offshore Platform Responses. Int. J. Non-Linear Mech. 2007, 42, 555-565. [CrossRef]

156. Lim, D.-H.; Kim, Y. Probabilistic Analysis of Air Gap of Tension-Leg Platforms by A Nonlinear Stochastic Approach. Ocean Eng. 2019, 177, 49-59. [CrossRef]

157. Somayajula, A.; Falzarano, J. Large-Amplitude Time-Domain Simulation Tool for Marine and Offshore Motion Prediction. Mar. Syst. Ocean Technol. 2015, 10, 1-17. [CrossRef]

158. Guha, A.; Somayajula, A.; Falzarano, J. Time Domain Simulation of Large Amplitude Motions in Shallow Water. In Proceedings of the 21st SNAME Offshore Symposium, Society of Naval Architects and Marine Engineers, Houston, TX, USA, 16 February 2016; pp. 1-20.

159. Romolo, A.; Malara, G.; Laface, V.; Arena, F. Space-Time Long-Term Statistics of Ocean Storms. Probabilistic Eng. Mech. 2016, 44, 150-162. [CrossRef]

160. Ding, W.; Pang, L. Structural Fatigue Assessment of Offshore Platform Considering the Effect of Nonlinear Drag Force. In Proceedings of the 35th International Conference on Ocean, Offshore and Arctic Engineering, Busan, Korea, 18-24 June 2016.

161. Faulkner, D.; Cowling, M.; Incecik, A. Integrity of Offshore Structures; CRC Press: Boca Raton, FL, USA, 1991.

162. Mansour, A.E.; Ertekin, R.C. Ships and Offshore Structures. In Proceedings of the 15th International Ship and Offshore Structures Congress: 3-Volume Set, San Diego, CA, USA, 11-15 August 2003.

163. Natarajan, A. Influence of second-order random wave kinematics on the design loads of offshore wind turbine support structures. Renew. Energy 2014, 68, 829-841. 